\title{
Wild plants and fungi sold in the markets of Yerevan (Armenia)
}

\author{
Siranush Nanagulyan ${ }^{1}$, Narine Zakaryan ${ }^{1}$, Nune Kartashyan ${ }^{1}$, Renata Piwowarczyk ${ }^{2}$ and $Ł u k a s z ~ Ł u c z a j^{3^{*}}$ (D)
}

\begin{abstract}
Background: The aim of the study was to record wild plants and fungi sold in the capital of Armenia. This is the first large market survey in the Caucasus region. The area of the Caucasus is characterised by a very high diversity of climates, flora and languages which results in very rich traditions of plant use.

Methods: Interviews were conducted and photos and voucher specimens were taken during multiple visits made over 4 years. We studied 37 locations and 136 people were interviewed.

Results: As many as 163 plant species, belonging to 44 families and 110 genera, were recorded on Yerevan markets. This included 148 wild food species, 136 medicinal species, 45 species sold for decoration, 15 species of wood and 9 species of insect repellents. Also 14 wild species of fungi were sold, including 12 food species.

Conclusions: The list of plants sold in the markets of Yerevan is very extensive and diverse, and includes many species of wild fruits, vegetables and medicinal plants, some of them never listed in ethnobotanical directories before. A characteristic feature of this market is a large representation of lacto-fermented products. Some of the species sold in Yerevan have never been reported as human food either in wild edible plant word lists or in ethnobotanical publications, e.g. Angelica tatianae, Ferulago setifolia and Heracleum chorodanum. Fungi are also well represented.
\end{abstract}

Keywords: Ethnobotany, Ethnomycology, Open-air markets, Caucasus, Edible plants and fungi, Food plants, Medicinal plants

\section{Background}

The Caucasus is one of the richest regions of Eurasia in terms of biocultural diversity as well as being one of the globe's most important biodiversity hotspots [1]. In the Caucasus, a large number of climate types and high altitudinal variation is combined with high ethnic diversity. The Caucasus Mountains host more languages than the rest of Europe [2, 3]. The large diversity of economic plants and their uses was recorded by botanists and agriculturalists from the Soviet Union, including Grossgeim and Vavilov $[4,5]$. Presently a new era of detailed ethnobotanical exploration of the Caucasus has begun. It

\footnotetext{
*Correspondence: lukasz.luczaj@interia.pl

${ }^{3}$ Institute of Biology and Biotechnology, University of Rzeszów, Pigonia 1, 35-310 Rzeszów, Poland

Full list of author information is available at the end of the article
}

consists of detailed ethnobiological exploration (e.g. [6$18])$. In-depth local studies have revealed many interesting, and sometimes unique, plant uses.

Open-air markets hold an important position for ethnobotanists and ethnomycologists. Ethnobotanical studies of open-air markets are a frequent topic of ethnobotanical enquiry, as they are places where one can usually find plants that are the most important to a given culture, e.g. commonly eaten fruits, vegetables or medicinal plants (e.g. [18-56]). The oldest known ethnobiological market surveys were carried out in the 1920s by Pénzes in Hungary [24, 25] and Polish researchers: in the 1920s in Wilno/Vilnius (now the capital of Lithuania) by Muszyński [21] and in the 1930s in Poznań, Poland (Szulczewski) [22, 23]. Another important 
early work based on market surveys is the study of Bye from Mexico [19].

The ethnobiological diversity of organisms sold in open-air markets in the Caucasus has only been explored in two papers from Georgia, one about medicinal plant mixes in Borjomi [18], the other on wild vegetables sold in the markets of Kutaisi [10].

There has always been a great demand for wild plants amongst the Armenian population. They have benefited from the use of various wild plants since ancient times, and they have passed on their traditions from generation to generation. The herbs of the Armenian Highlands were highly praised by the Greek physician, pharmacologist, botanist and author of De Materia Medica, Pedanius Dioscorides [57]. Traditionally, Armenians have used plants as food, medicine, fuel, construction material, dyes for carpet yarns, insect repellent and for other purposes.

The Armenian flora is represented by around 3800 species of vascular plants from 160 families and 913 genera, including 146 endemic species. It is estimated that about $20 \%$ of the species composition of the flora of Armenia is in use by its population [16]. Amongst these plants, about 380 species have medicinal applications used in traditional folk medicines, approximately 90 species are used in scientific medicine, and around 320 species are traditionally used edible plants. It is estimated that out of the 1400 species of macroscopic fungi in the country, at least 300 edible, 60 poisonous and more than 120 species with medicinal properties have been recorded. However, the traditional use of mushrooms in Armenia is little studied [58].

\section{Methods}

\section{Aim of study}

The aim of the study was to document the taxonomic diversity and uses of the wild plants and fungi sold in the capital of Armenia, Yerevan.

\section{Study area}

Armenia is a southern Caucasian republic with a total area of $29,740 \mathrm{~km}^{2}$, bordered by Georgia, Azerbaijan, Turkey and Iran. Armenia is a mountainous country, dominated by a series of mountain massifs and valleys, with its lowest point at $375 \mathrm{~m}$ above sea level and culminating at $4095 \mathrm{~m}$ (Mt Aragats-extinct volcano) with an average elevation of $1850 \mathrm{~m}$ [59]. About $90 \%$ of the country lies at an altitude of over $1000 \mathrm{~m}$ above sea level and is located in a seismically active area. It is home to Sevan, the largest lake in the Caucasus (area $1240 \mathrm{~km}^{2}$ ), a tectonic ditch at an altitude of $1900 \mathrm{~m}$ above sea level. The diversity of landscapes, climates ( 6 basic types, from dry subtropical up to extreme alpine) and orography is an important determinant of Armenia's vegetation. The lower mountain belt $(375-1200 \mathrm{~m})$ is represented by semi-desert or phryganoid formations (i.e. vegetation

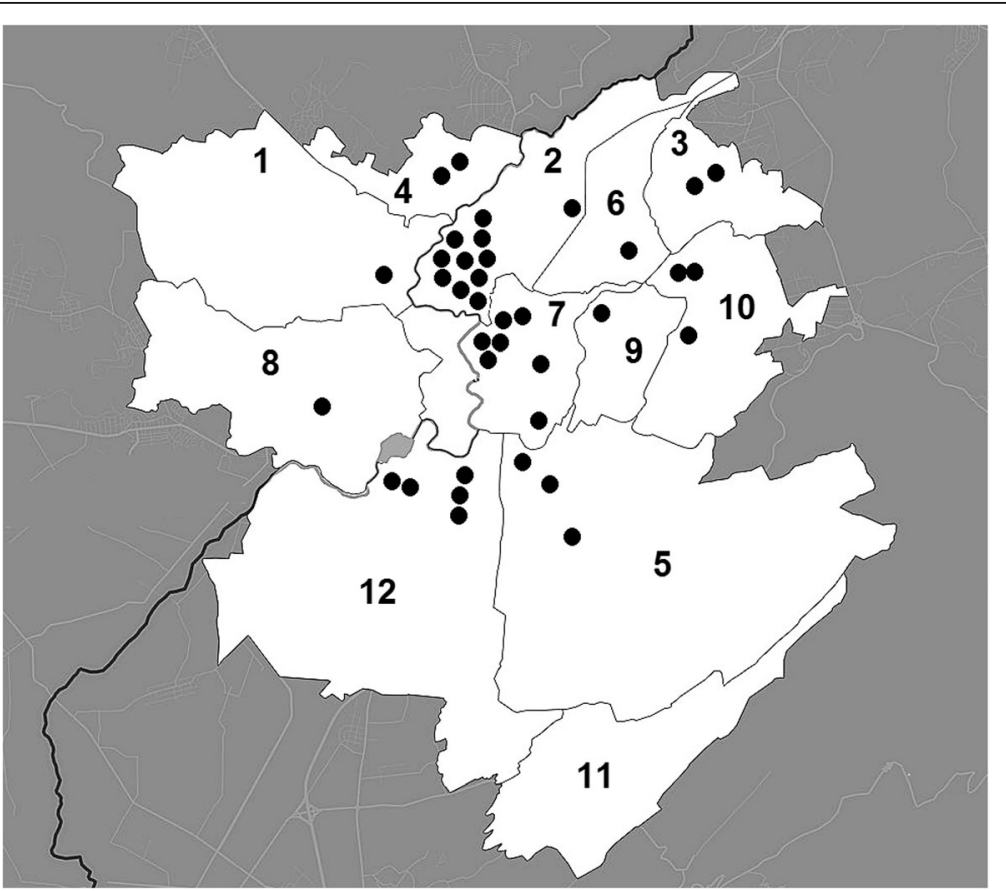

Fig. 1 Distribution of studied market places (black dots) in administrative districts of Yerevan: 1. Ajapnyak, 2. Arabkir, 3. Avan, 4. Davtashen, 5. Erebuni, 6. Kanaker-Zeytun, 7. Kentron, 8. Malatia-Sebastia, 9. Nork-Marash, 10. Nor Nork, 11. Nubarashen, 12. Shengavit 

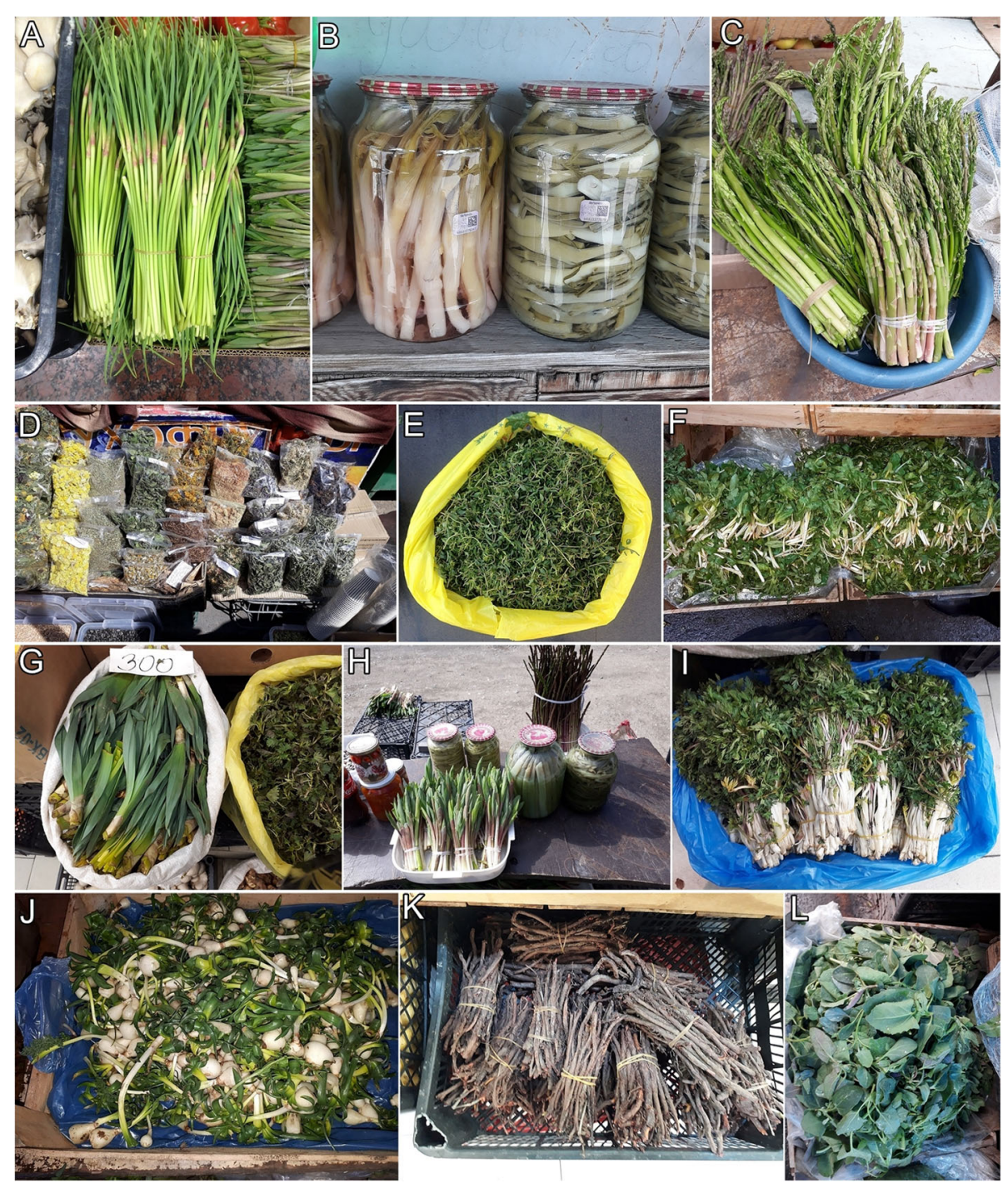

Fig. 2 Wild plants sold in the markets of Yerevan a Allium victorialis. b Chaerophyllum bulbosum (pickled) and Bilacunaria microcarpa (pickled). c Asparagus officinalis. d Helichrysum sp., Thymus sp., Pinus kochiana, Hypericum sp., Tanacetum sp., Salvia sp., Valeriana officinalis, Cichorium intybus, Inula helenium, Mentha piperita, Leucanthemum vulgare. e Ziziphora clinopodioides. f Falcaria vulgaris. $\mathbf{g}$ Eremurus spectabilis, Urtica dioica. $\mathbf{h}$ Polygonatum orientale. i Chaerophyllum aureum. j Ornithogalum montanum, k Rubia tinctorum roots. I Chenopodium album

dominated by small, fragrant, prickly semishrubs of the Lamiaceae, Asteraceae family and Astragalus, Euphorbia genera), gypsophilous or halophilous vegetation, salt marsh areas, as well as the Transcaucasian sand desert. The middle and upper mountain belts (1200-2200 m) are characterised by diversified steppe and forest vegetation, meadow-steppes, shrub steppes and thorny cushion (tragacanth) vegetation. The altitudinal span of the forest belt varies from 500 to $1500-2000 \mathrm{~m}$. The subalpine and alpine belts $(2200-4000 \mathrm{~m})$ are covered by tall-grass vegetation, meadows and carpets, with an abundance of biocoenoses, rich species composition and a high level of endemism [60-63].
Yerevan, the capital of Armenia, dates back to the 8th century $\mathrm{BC}$ and is one of the world's oldest continuously inhabited cities. It is situated along the Hrazdan River and is the administrative, cultural, and industrial centre of the country, where more than half of the country's inhabitants are concentrated. According to an official estimate from 2016, the city has a current population of 1,073,700 [64]. The city used to be an important centre for trade and came under siege from the Romans, Arabs, Mongols, Turks, Persians, Georgians, and Russians. These various foreign influences, mixed and evolving for centuries, are still visible today, e.g. in the architecture, traditions, and of course in the use of wild plants or spices in cooking. 
The city of Yerevan is divided into 12 administrative districts, and each of them has its own market. The largest markets are located in the Kentron, Arabkir and Malatia-Sebastia districts. Yerevan's surroundings belong to the Yerevan Floristic Region, with vertical altitudes from 700 to $1700 \mathrm{~m}$ above sea level. The main floristic inventory work focused on the region around Yerevan was performed between the 1950s and 1980s. During a period of economic blockade and energy crisis (19921995), woody vegetation was extensively cut down, especially in the vicinity of hills around Yerevan, which has led to the increased erosion of soils on hillsides.

The flora of the Yerevan Floristic Region counts 1920 species, from which 46 species are endemic, and 144 species included in the Red Book of Armenia $[16,65]$. The low mountain belt of the region $(700-1200 \mathrm{~m})$ is covered by semi-desert or phryganoid formations, gypsophilous and halophilous vegetation. There are salt marsh areas as well as the Transcaucasian sand desert. The middle and upper mountain belts $(1200-1700 \mathrm{~m})$ are characterised by various kinds of steppe vegetation, shrub steppes and thorny cushion (tragacanth) vegetation $[16,66]$.

\section{Data collection}

Ethnobotanical and ethnomycological information was gathered using unstructured or semi-structured interviews and focus group discussions with city population and sellers in the markets. The observations were made in Yerevan between 2016 and 2019 in 37 open-air and farm markets, supermarkets, streets shops and other locations where wild plants and fungi were sold (Appendix 1; Fig. 1). The interviews were conducted in every month throughout the year. During the interviews, fresh or dried plant and fungi samples were collected as voucher specimens where possible. In some cases, the plants were also collected from nature. A total of 136 respondents were interviewed. The age of them varied from 20

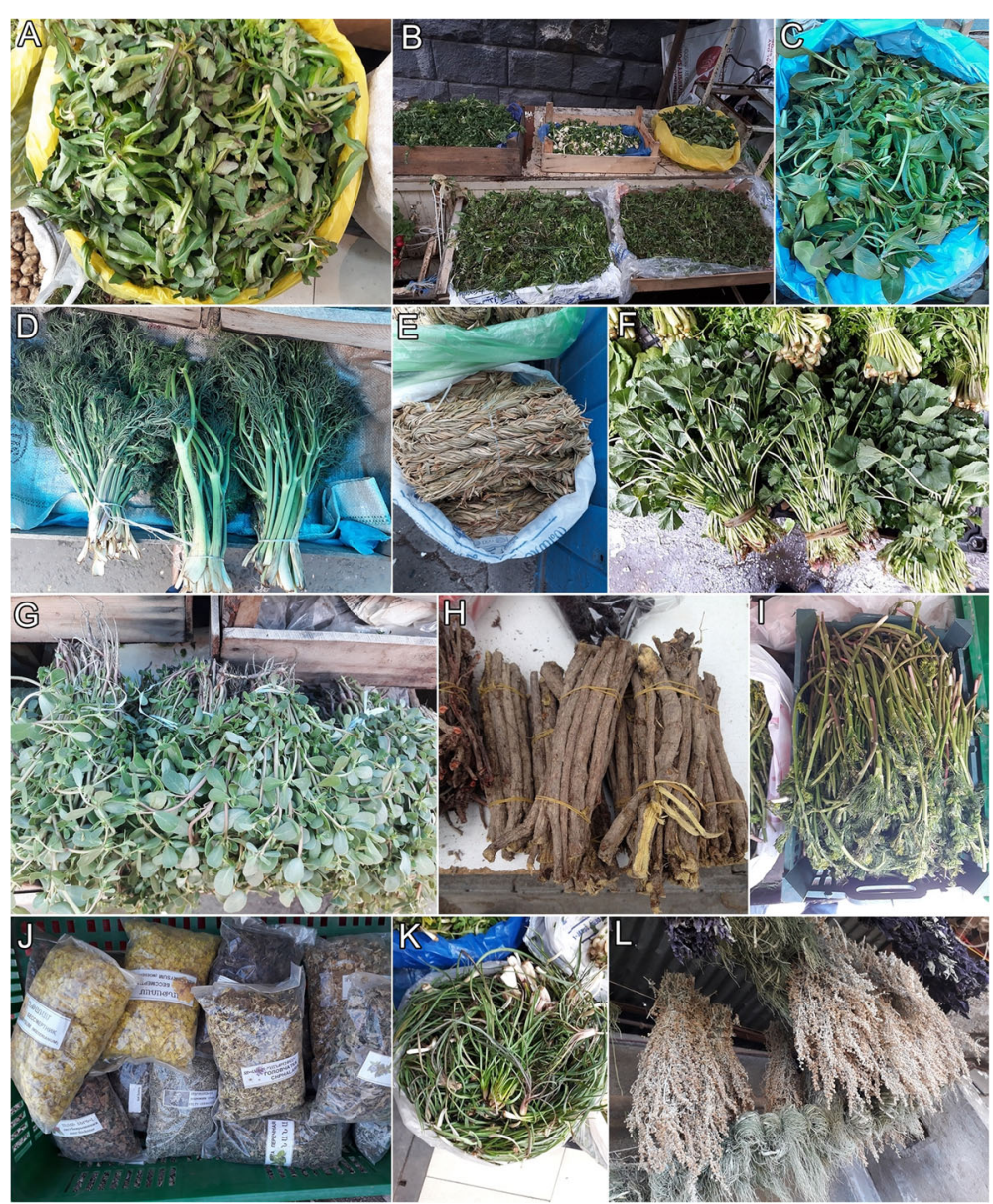

Fig. 3 Wild plants sold in the markets of Yerevan. a Lactuca serriola. b Urtica dioica, Ornithogalum montanum, Senecio vernalis. c Lepidium draba. d Bilacunaria microcarpa. e Ornithogalum hajastanum dried. f Malva neglecta. g Portulaca oleracea. h Glycyrrhiza glabra. i Ferulago setifolia. j Teucrium polium, Cephalaria gigantea, Crataegus sp., Helichrysum rubicundum. k Tragopogon sp., I Artemisia absinthium, Equisetum arvense 
to 80 . Most respondents were women (83\%) and only $17 \%$ were men. Respondents were asked about the traditional uses of the plants and fungi that were for sale, local names of species, their therapeutic effects and methods of preparation and cooking.

The plants and fungi were identified by the authors using the Flora of Armenia [67], the Mycoflora of Armenia Soviet Socialist Republic [68] and Cap Fungi of Armenia [69]. Voucher specimens were deposited at the Herbarium of the Yerevan State University (ERCBplants, ERHM-fungi). Plant names were updated according to the Plant List [70]. Fungi names follow Index Fungorum [71].

Some of the taxa included in the list of species (Appendix 2) are often cultivated (e.g. Morus, Ficus, Punica). However, we included them in the list because they also often occur in a wild or semi-wild state.

\section{Results}

Altogether 163 plant species have been recorded on Yerevan markets during this study (Appendix 2; Figs. 2, 3 and 4). They belong to 44 families and 110 genera. The most common plant families are Asteraceae (20\%), Rosaceae (14\%), and Apiaceae (11\%). Tragopogon and Crataegus (both 6 species) are used the most. As many as 17 species of fungi are sold in open-air markets including 14 species collected from the wild and three species cultivated for food. Most of the mushrooms, namely 12 species, are wild species sold for culinary purposes (Appendix 2; Fig. 5).

As many as 148 plant species are sold for food, 136 species are sold as medicine or are food species with perceived medicinal values, 45 species are decorative plants, 15 plants are a source of wood and nine species are used as an insect repellent.

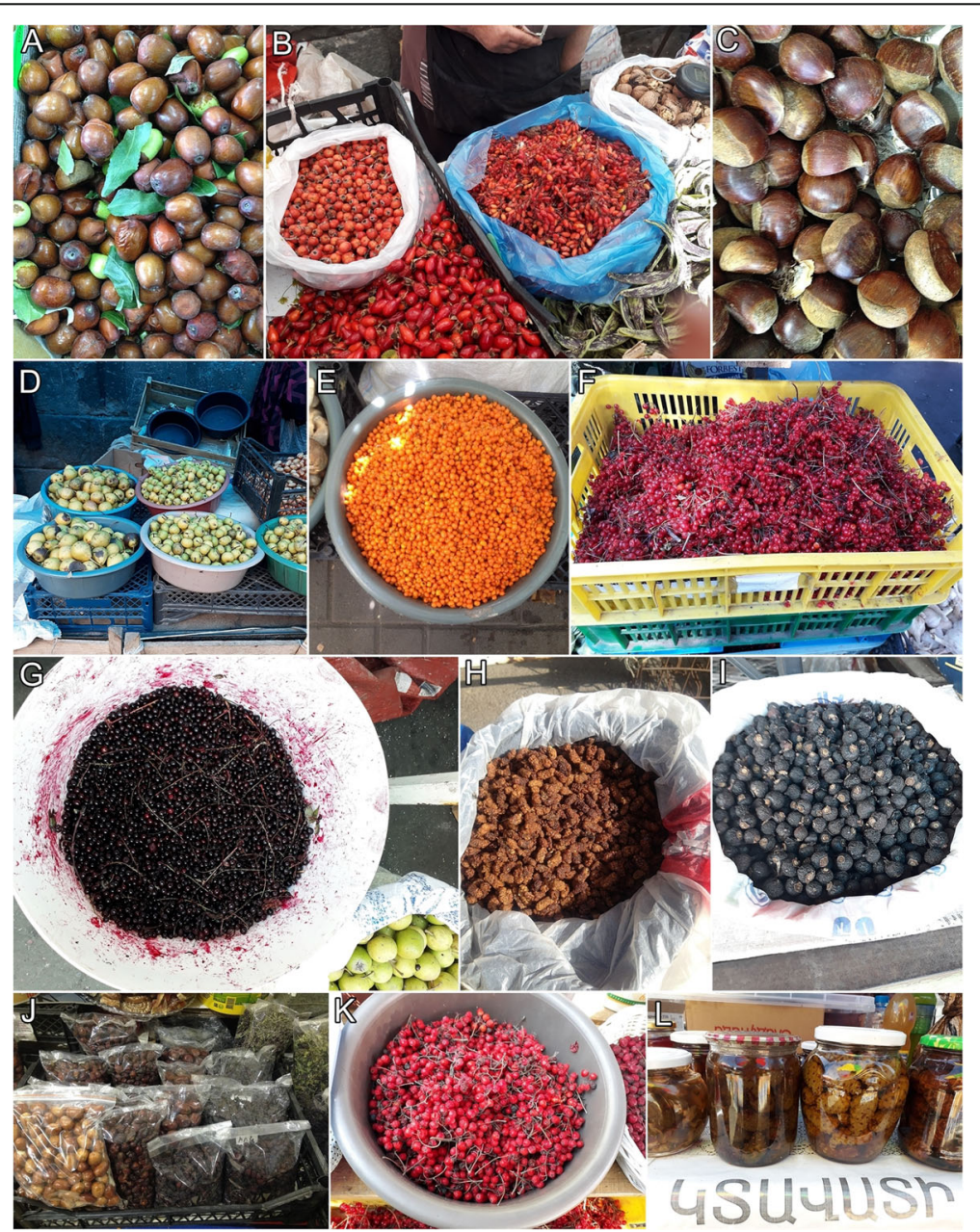

Fig. 4 Wild fruits and nuts sold in the markets of Yerevan. a Ziziphus jujuba. b Berberis vulgaris, Rosa canina, Crataegus orientalis. c Castanea sativa. d Pyrus calicifolia, P. caucasica. e Elaeagnus rhamnoides. f Viburnum opulus. g Ribes petraeum. h Morus alba. i Rosa spinosissima. $\mathbf{j}$ Elaeagnus angustifolia, Rosa sp., Cornus mas. k Sorbus aucuparia. I Pinus kochiana jam and tincture of female cones 


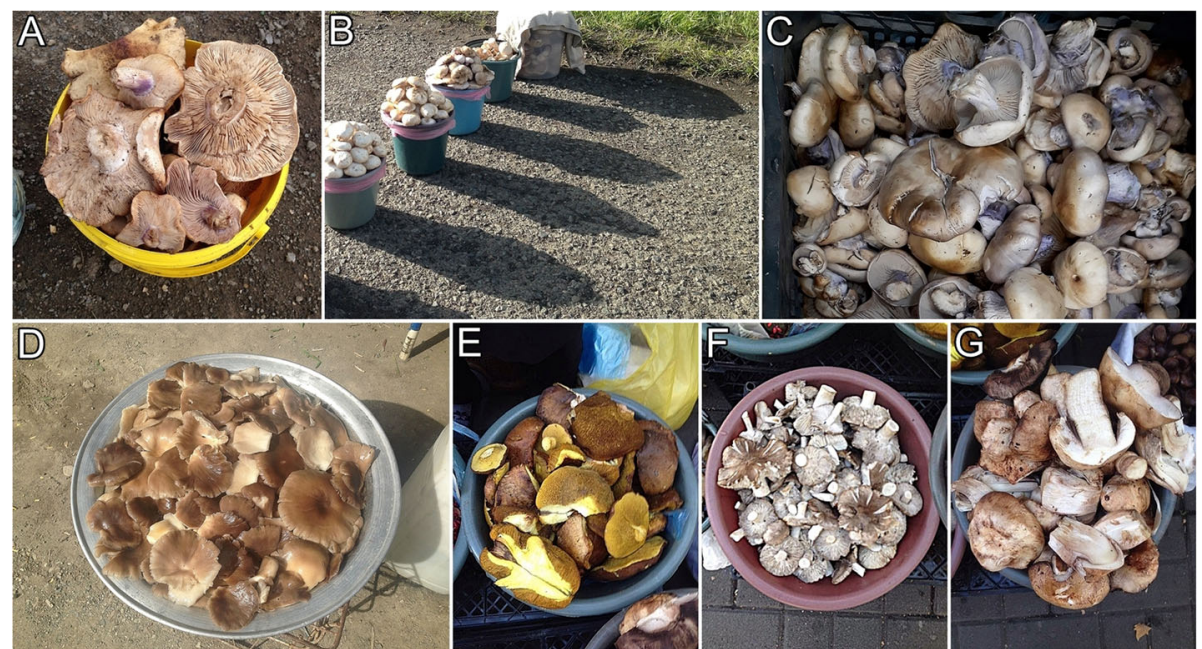

Fig. 5 Wild mushrooms sold in the markets of Yerevan. a Lepista personata. b Agaricus campestris and Lepista personata. c Lepista nuda. d Pleurotus ostreatus. e Suillus granulatus. f Tricholoma terreum. g Agaricus bisporus

The largest category of species sold in the markets is those used for food. The most commonly sold and used food species are Rumex crispus, Chaerophyllum bulbosum, Astrodaucus orientalis, Malva neglecta, Falcaria vulgaris, Asparagus officinalis, A. verticilata, Eremurus spectabilis, Urtica dioica and Polygonatum orientale (for authority names cited in the text, see Appendix 2 for plants and Table 1 for fungi).
Wild food plants are used for a variety of dishes (Fig. 6). Young leaves of Stellaria media, Anthriscus nemorosa, Capsella bursa-pastoris, Urtica dioica, Mentha longifolia, Allium spp., Tragopogon spp., and Rumex spp. serve as filling for pies called zhingyalov hats, a type of flatbread stuffed with finely diced herbs. Young leaves of Vitis vinifera are used to wrap dolma (stuffed leaves with meat). Young leaves of Chaerophyllum aureum, fried

Table 1 Fungi sold in Yerevan's markets

\begin{tabular}{|c|c|c|c|}
\hline Species & Voucher number (ERHM) & Widely used Armenian name & Ways of use \\
\hline Agaricus arvensis Schaeff. & 10764 & Shampinion & CUL: Fried, boiled \\
\hline Agaricus bisporus (J.E. Lange) Imbach ${ }^{a}$ & 10683 & Shampinion & CUL: Fried, boiled, lacto-fermented \\
\hline Agaricus campestris L. ${ }^{a}$ & 10629 & Shampinion & CUL: Fried, boiled, lacto-fermented \\
\hline Armillaria sp. & 10190 & Kotchghasunk & CUL: Fried, boiled \\
\hline Calocybe gambosa (Fr.) Donk & 11080 & Sharqasunk, garan dmak & CUL: Fried, boiled \\
\hline Cantharellus cibarius Fr. & 10774 & Aghvesasunk & CUL: Fried, boiled, lacto-fermented \\
\hline Fomes fomentarius (L.) Fr. & 11079 & Abetasunk & DEC: Fruiting bodies used as decorative elements \\
\hline Ganoderma lucidum (Curtis) P. Karst. & 10424 & Laqapat abetasunk & $\begin{array}{l}\text { MED: Sold to be used in Chinese medicine. } \\
\text { DEC: Fruiting bodies used as decorative elements }\end{array}$ \\
\hline Lactarius deliciosus (L.) Gray & 11081 & Sheklik & CUL: Fried, boiled, lacto-fermented \\
\hline Lactarius deterrimus Gröger & 10328 & Sheklik & CUL: Fried, boiled, lacto-fermented \\
\hline Lepista nuda (Bull.) Cooke & 10692 & Kapuyt sunk & CUL: Fried, boiled \\
\hline Lepista personata (Fr.) Cooke & 10694 & Kapuyt votikov sunk & CUL: Fried, boiled \\
\hline Marasmius oreades (Bolton) Fr. & 10633 & Kochghasunk dashti & CUL: Fried, boiled \\
\hline Pleurotus eryngii (DC.) Quél. & 10783 & Tagavorakan akandjasunk & CUL: Fried, boiled, lacto-fermented \\
\hline Pleurotus ostreatus (Jacq.) P. Kumm. ${ }^{a}$ & 10782 & $\begin{array}{l}\text { Akandjasunk, kakhasunk, } \\
\text { tsari sunk, vostresunk }\end{array}$ & CUL: Fried, boiled, lacto-fermented \\
\hline Suillus granulatus (L.) Roussel & 10502 & Yuxhasunk & CUL: Fried, lacto-fermented \\
\hline Tricholoma terreum (Schaeff.) P. Kumm. & 10604 & Sharqasunk mokhraguyn & CUL: Fried, lacto-fermented \\
\hline
\end{tabular}




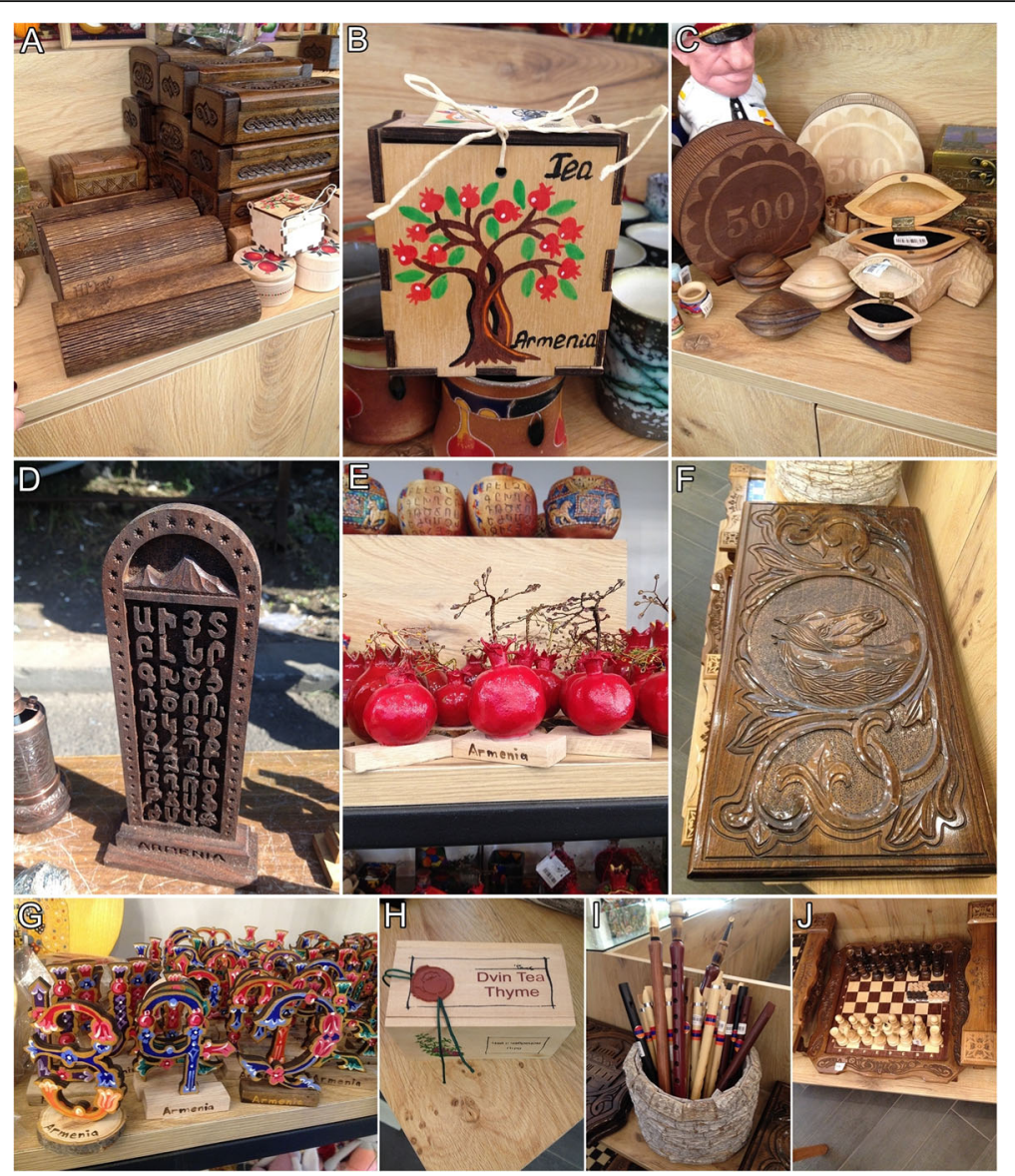

Fig. 6 Handicrafts made from wild woods sold in the markets of Yerevan. a Prunus armeniaca case for glasses. b Fagus orientalis wooden box for tea. $\mathbf{c}$ Handicrafts of Prunus armeniaca - moneyboxes and jewellery boxes. $\mathbf{d}$ Prunus armeniaca, wooden handicraft. e Pomegranates from wood. $\mathbf{f}$ Fagus orientalis wood backgammon. $\mathbf{g}$ Handicrafts of Prunus armeniaca. $\mathbf{h}$ Prunus divaricata wooden box for tea. $\mathbf{i}$ Wooden musical instruments (duduk, shvi). j Fagus orientalis and Prunus divaricata wooden chess

with eggs, are called tapakats shushan and a similar dish made with C. bulbosum called tapakats mandak. Young leaves of Falcaria vulgaris are also commonly fried with eggs for a dish called tapakats sibekh. Fruiting bodies of Lepista personata and Agaricus campestris are combined with Triticum dicoccon (emmer wheat) for the Armenian pilav-acharov plav.

Inhabitants of the city also use some plants for salads, e.g. Urtica dioica, Portulaca oleracea and Rumex acetosa. Soups are made with different species of Malva and Rumex, and with Puschkinia scilloides. A larger variety of dishes is prepared from Asparagus officinalis, A. verticillatus, Astrodaucus orientalis, Capsella bursa-pastoris, Chaerophyllum aureum, C. bulbosum, Eremurus spectabilis, Falcaria vulgaris, Hippomarathrum microcarpum, Lactuca serriola, Lepidium draba, L. latifolium, Ornithogalum hajastanum, Polygonatum giaberrimum, P. multiflorum, $P$. orientale, different species of Tragopogon and Rumex.
Artemisia absinthium, Berberis vulgaris, B. orientalis, Carum carvi, Origanum vulgare, Thymus spp. and Ziziphora rigida are used as flavouring. Different species of Thymus and Allium are commonly used for flavouring cheese and curd.

Numerous species are used to make recreational teas, e.g. Rosa spp., Mentha longifolia, Cephalaria gigantea, Origanum vulgare and different species of Thymus. Juglans regia, Prunus armeniaca, Corylus avellana and seeds of Cannabis sativa are used as edible nuts. As for berries and fruits, locals buy Cornus mas, Elaeagnus angustifolia, E. orientalis, E. rhamnoides, Ficus carica, Morus alba, M. nigra, Prunus armeniaca, $P$. divaricata, Punica granatum, Ribes alpinum, Viburnum opulus, Ziziphus jujuba and different species of Crataegus.

The species which are sold and used most frequently as medicinal remedies in the city of Yerevan include Artemisia absinthium, Hypericum perforatum, Mentha longifolia, Origanum vulgare, Teucrium polium and 


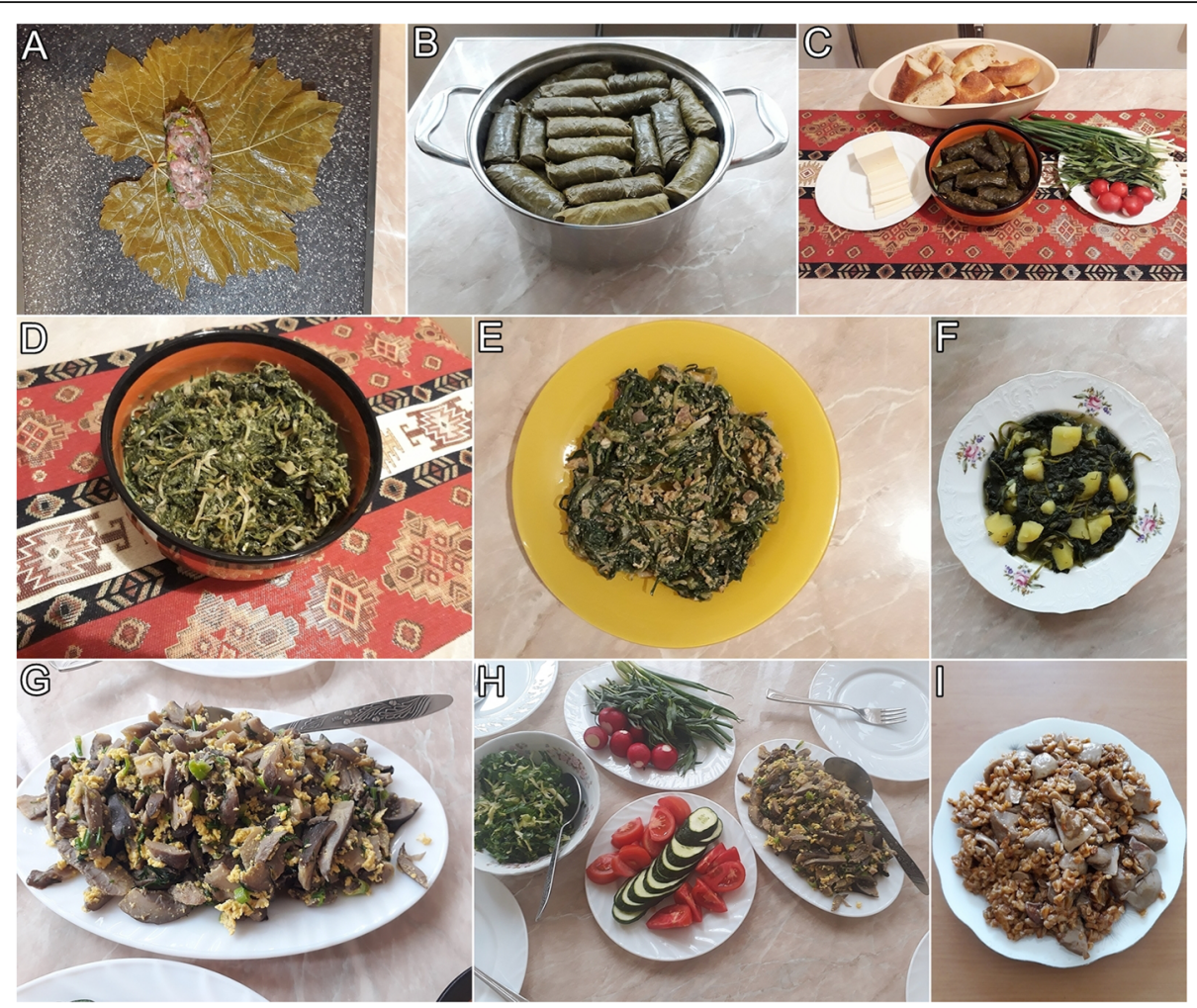

Fig. 7 Selected dishes using wild plants and mushrooms from the markets of Yerevan. $\mathbf{a}, \mathbf{b}, \mathbf{c}$ Young stuffed leaves of grape Vitis vinifera with meat for dolma. d Falcaria vulgaris fried. e F. vulgaris fried with eggs. f Malva neglecta (soup with potatoes) —Pipertov apur. g Pleurotus ostreatus with eggs. $\mathbf{h}$ fried Ornithogalum montanum (left) and fried Pleurotus ostreatus with eggs (right). i Lepista personata with Triticum dicoccon (emmer)-Acharov plav

three species of genus Thymus-T. kotschyanus, T. rariflorus, T. transcaucasicus. The most common types of remedies are those for the treatment of digestive disorders, the common cold and other respiratory problems.

An important segment of wild plants is the wood (Fig. 7) used for manufacturing musical instruments, like Prunus armeniaca (used to make duduk, tar, qyamancha, and zurna), P. divaricata (for saz) and different national handicrafts and souvenirs (the wood of Fagus orientalis, Juglans regia and Prunus armeniaca). Fruit bodies of Fomes fomentarius and Ganoderma lucidum commonly are used as decorative elements.

\section{Discussion}

The presented list of useful plants sold in Yerevan consists of diverse categories, including both food and medicine, as well as other smaller categories. This diversity of plant uses brings studies of both southwest and southeast Asian markets to mind. In Table 2, we put together other publications on the ethnobotany and ethnomycology of markets in different parts of Eurasia. Out of studies concerning more than one plant category, the largest number of species was recorded in the market of Bodrum, Turkey, with as many as 390 species [29]. In Turkey, similarly to Yerevan, large numbers of wild vegetables and medicinal plants are sold. The number of edible plants recorded was 143 but the number of fungi species was 7 (compared to 17 in our study). Unfortunately, we do not have lists of plants from other large towns of the Caucasus region to make local comparisons. In Kutaisi in Georgia, Łuczaj et al. [10] have recorded sales of 26 species of wild vegetables, while the number of species sold in Yerevan is much larger, with as many as 65 different species. In contrast to Yerevan, few wild vegetables are sold in the open markets of Central Europe, e.g. Poland and Hungary [41, 53] (mainly Rumex and Allium ursinum), and only a small portion of medicinal plants is sold [41, 53], though in the early 20th century, the medicinal sector in the markets of Poland was an important part of open-air markets [21-23]. But still, even in the 1920s and 1930s, the number of edible and medicinal plants for sale was lower than in contemporary Yerevan. On the other hand, the number of fungi sold in the markets of central Europe is higher than in Yerevan. For example, in southeastern Poland Kasper-Pakosz et al. [53] recorded the sales of 32 species, including 20 


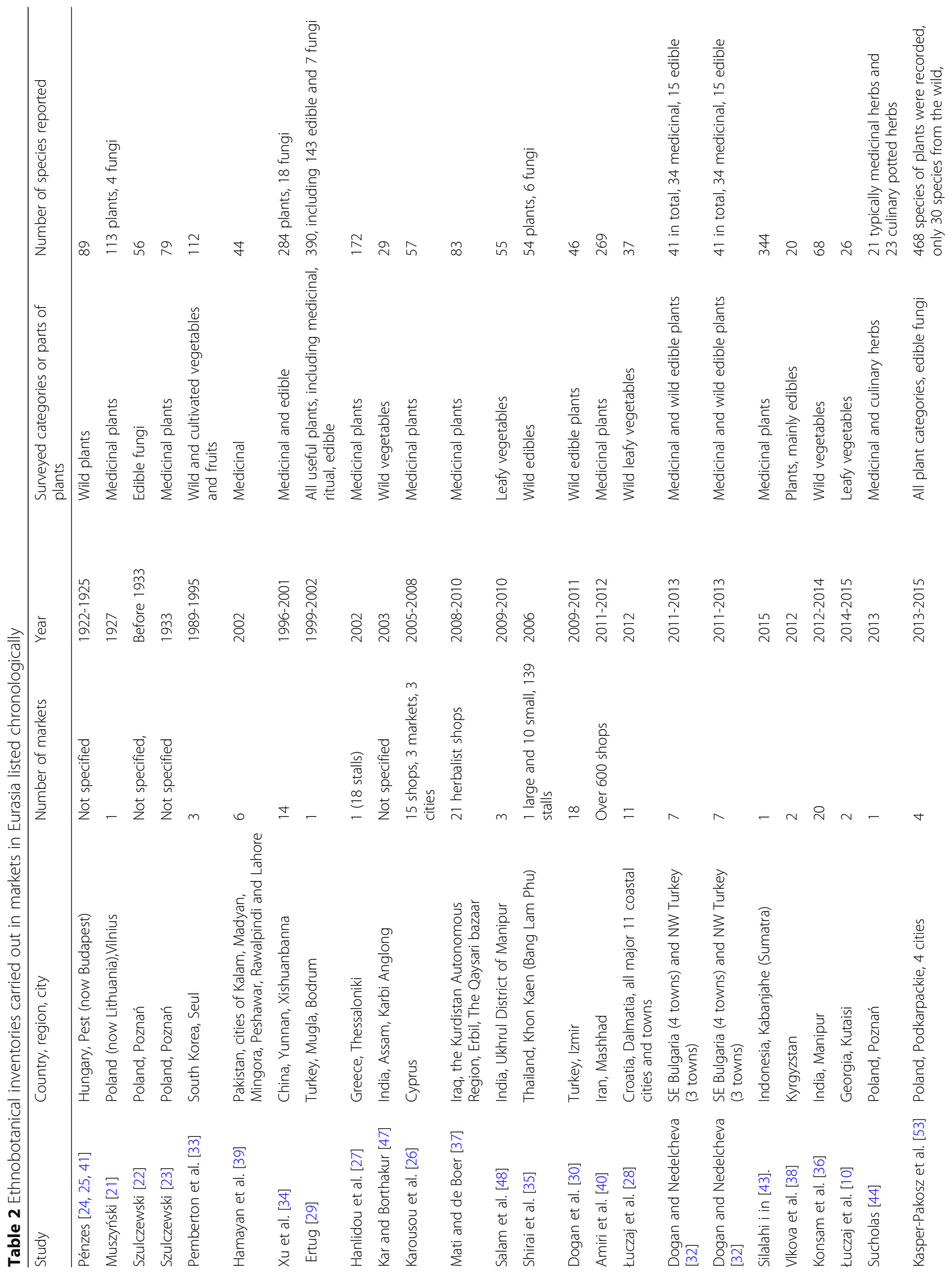




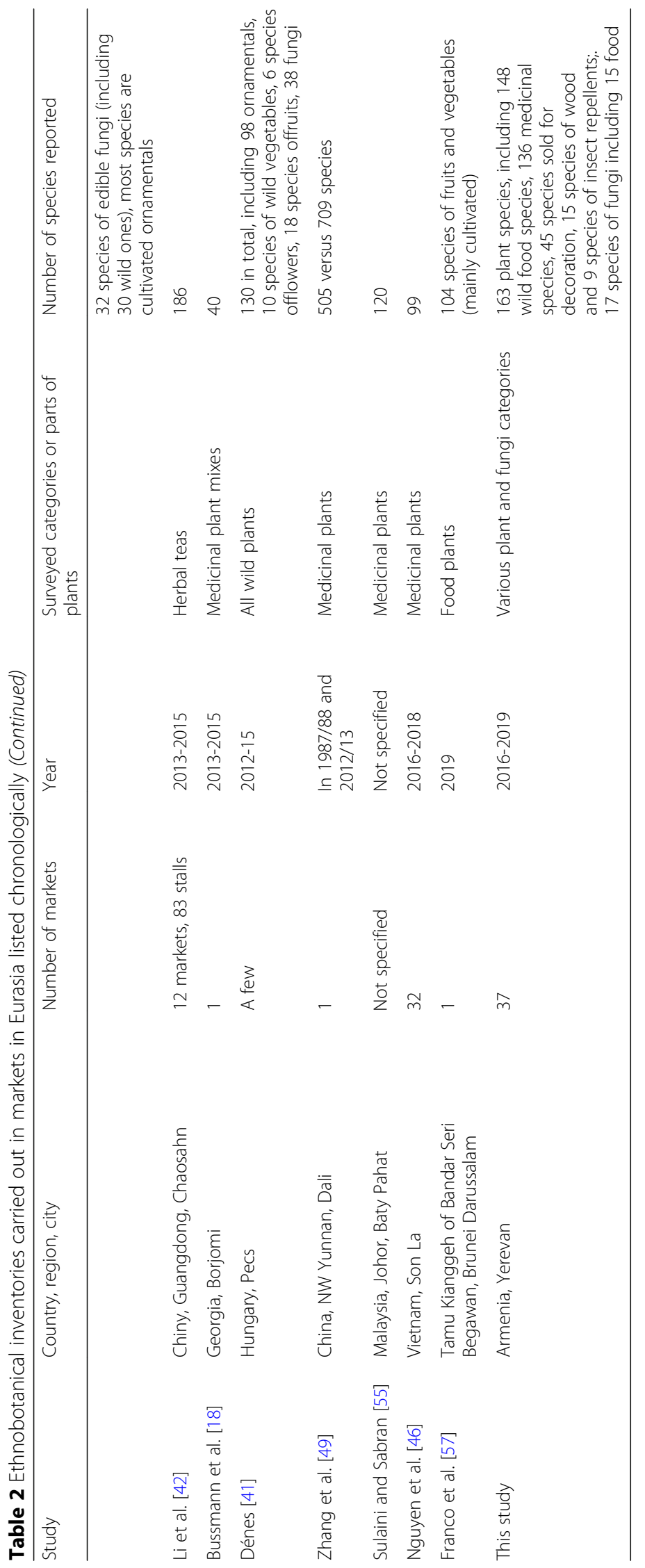




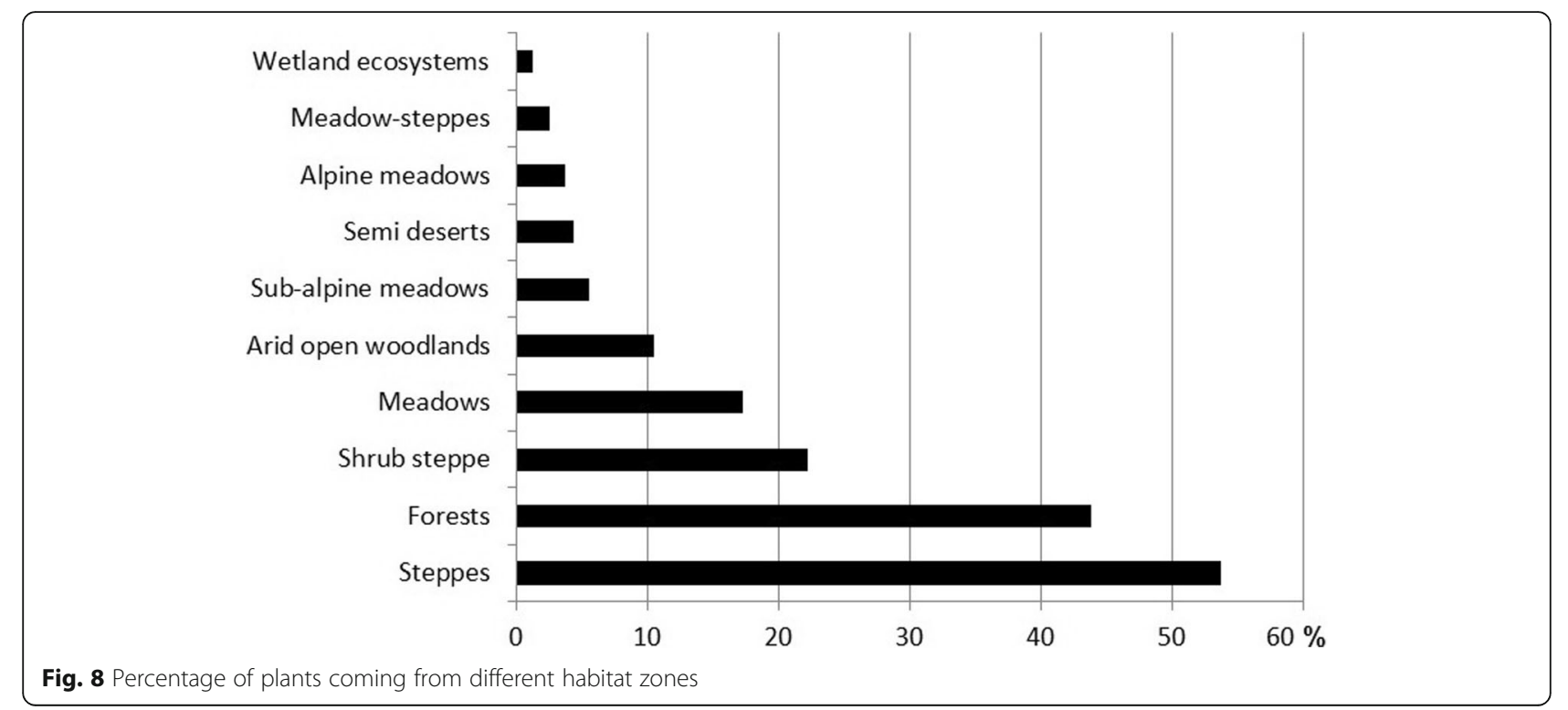

wild ones. Earlier in the 1930s, Szulczewski [22] recorded as many as 56 fungi species in Poznań. Of course, the number of species of fungi sold in Yerevan is still quite high-higher than in most south Asian markets. The large choice of wild vegetables and wild edible fungi must reflect the strongly herbophilic (sensu Łuczaj [72]) and mycophilic [73] approach of the inhabitants of Yerevan.

Most of the plants sold in the markets are relatively common. The main source of plants are the surrounding steppes and forests (Fig. 8). Only few species come from high altitudes or (semi)deserts. However, four Armenian Red List species have been recorded on Yerevan markets [65]. This includes three plant species: Acorus calamus with endangered status-EN B 1 ab (i, ii, iii, iv) + 2 ab (ii, iii); Castanea sativa, endangered-EN B 1 ab (iii) +2 ab (iii) and Ferula szowitsiana, vulnerable-VU B 1ab (ii, iii, iv) + 2 ab (ii, iii, iv), as well as one species of fungus, Pleurotus eryngii, vulnerable-VU. We suspect that $F$. szowitziana, A. calamus and $P$. eryngii can be affected by harvesting from the wild, as $C$. sativa is cultivated.

A characteristic feature of Yerevan markets is the many species of lacto-fermented products sold in jars. These include many wild plant species. In our study, we recorded 26 species of plants preserved in this way, including as many as 11 species from the Apiaceae. The wide use of wild Apiaceae as food, e.g. from the genera Heracleum, Anthriscus, and Chaerophyllum, seems to be a characteristic feature of the whole Caucasus area (e.g. [6, 14, 17, 74] and Anna Janicka-Galant, Łódź, pers. comm.). We recorded also 9 species of fungi, which are used as lacto-fermented products, e.g. from the genera Agaricus, Lactarius and Pleurotus. The context of fermented foods and their documentation is important due to their growing popularity and possible health benefits $[75,76]$.

Apart from wild foods that are commonly found in Caucasian, European and south Asian markets, some of the species sold in Yerevan have never been reported as human food either in wild edible plant word lists or in ethnobotanical publications. These include some plants from the Apiaceae family: Angelica tatianae, Ferulago setifolia and Heracleum chorodanum. Two species (Heracleum antasiaticum and Bilacunaria microcarpa), also from Armenia, have only recently been reported as food a few weeks ago [17].

Surprisingly, Senecio leucanthemifolius subsp. vernalis is sold as a wild vegetable. This genus of ragworts is famous for a high content of pyrrolizidine alkaloids which have a hepatotoxic and carcinogenic effect on humans [77]. Thus, further studies are needed to assess the safety of some species sold in the market. Similar controversies were discussed for the plants sold in a Georgian market where Symphytum, also rich in these alkaloids, is sold for consumption [10]. Arum orientale, with acrid and irritating properties due to the presence of crystals of oxalic acid, is another controversial species. As described in Appendix 2 only thorough drying and further thermal processing ensures the safe consumption of this plant.

There is a large overlap between medicinal and food species (Appendix 2). This overlap is expressed for example by the use of the same species for teas both for recreational use and medical purposes, and as spices (e.g. Artemisia, Thymus, Hypericum perforatum). Medicinal attributes of wild foods are also widely known. 
Good examples of plant use on a food-medicine continuum include the fruit syrup from Morus alba and M. nigra or sweets made from the cones of Pinus kochiana, which are sweets used for the treatment of coughs and respiratory system diseases. The powder of Glycyrrhiza glabra roots and rhizomes added to the traditional Armenian bread (lavash) is used for the same ailments. The persistence of such a food-medicine continuum occurs in many societies throughout the world [78, 79], including Eurasia [80-83].

The importance of local products that are often derived from wild food for Armenian economy was already noticed by Pieroni and colleagues [17]. In their paper, they made a list of wild products that could become important trading items to local inhabitants. Some of them, such as products made from the fruits of Rosaceae trees and shrubs and from Eleagnus spp., are already on sale in Yerevan. We would go even further and say that the many interesting lacto-fermented Apiaceae made in Yerevan could even become internationally recognised as part of a healthy cuisine, on the aforementioned wave of popularity of lactofermented products in general [76]. Pieroni et al. [17] and Slow Food [84] used the term foodscouting to describe the activity of looking for valuable local traditional food products. Market surveys play a large role in foodscouting as well. In countries with a very rich ethnogastronomic heritage like Armenia, food stalls enable the documentation of new foods and new processing techniques. We advocate for the documentation of plants sold in markets of selected urban centres in all the countries of the world. So far, we lack such documentation from other countries of the Caucasus, Central Asia and many East Asian countries.

Another interesting feature of Caucasian markets is the sale of dried wild vegetables. They are sold either in loose form (e.g. Ornithogalum hajastanum in Fig. 3) or entwined into circles for further boiling in winter. Drying wild vegetables and preserving them for winter is a sign of their high cultural importance and has survived as a practise only in few countries, mainly China [85]. In the past it was also recorded in Europe, e.g. in the present territory of Belarus, but the practise is now obsolete [86].

\section{Conclusions}

The Yerevan markets are rich in wild edible and medicinal plants and wild-collected fungi (sold mainly but not only for food). They are similar to other south Asian countries in this respect, and they are richer in edible and medicinal species than European markets. It is particularly worth noting the large number of lactofermented products for sale.
Further studies of plants and fungi sold in traditional open markets need to be made in other large towns of the Caucasus as well as in most countries that are not highly industrialised.

\section{Appendix 1}

The list of the surveyed markets

1. Arabkir Market - farm market, 53 Komitas Ave

2. Open-air market, 49 Marshal Baghramyan Ave

3. Open-air market, Komitas St

4. Parma Supermarket, 79 Marshal Baghramyan Ave

5. Mergelyan Shuka - farm market, 2 Hakob

Hakobyan St

6. Shirak Bazar - open-air market, Gyulbenkyan St

7. Yeritsyan \& Sons Supermarket, 21 Vahram Papazyan St

8. Gyughamej Eco shop, 18 Hrachya Qochar St

9. Nor Zovq Supermarket, 19 Gulakyan St

10. Aygedzor Supermarket, 2,1 Proshyan St

11. Skyurik Supermarket, 3,1/1 Nalbandyan St

12. Pak Shuka - farm market, 5 Mesrop Mashtots Ave

13. Open-air market, 7 Mesrop Mashtots Ave

14. Open-air market, 31 Mesrop Mashtots Ave

15. Open-air market, 50 Abovyan St

16. Open-air market, 7 Koryun St

17. GUM Market - farm market, 35 Movses Khorenatsi St

18. Open-air market, 52 Arshakunyats Ave

19. Fruit \& Vegetable store, 50 Arshakunyats Ave

20. Street shop, 46 Arshakunyats Ave

21. Kayarani Shuka - farm market, Sasuntsi David Square

22. Open-air market and streets shops, Garegin Nzhdeh Square

23. Streets shops, 3 Yeghbayrutian St

24. Open-air market and streets shops, 23-25 Azatutyan Ave

25. Zeytun Market - farm market, 51 Paruyr Sevaki St

26. Fruit \& Vegetable store, 123 Armenak Armenakyan St

27. Streets shops, Avan Alma Ata St

28. Streets shops, Marshal Babajanyan st

29. Malatya Agricultural Market, Raffi St

30. Nor Nork Farmers Market, Samvel Safaryan St

31. Palace Farmers Market, Nansen St

32. Streets shops, 14 Mikoyan St

33. Aresh Market, 80 Azatamartikner Ave

34. Streets shops, 111- 113 Muratsan St

35. Farmers Market, 15 Shinararneri St

36. Tsiran Supermarket, 44, 1 Tigran Petrosyan St

37. Gavar Fruit \& Vegetable store, 10 Tigran Petrosyan St 


\section{Appendix 2}

Table 3 Wild plants sold in Yerevan's markets

\begin{tabular}{|c|c|c|c|c|}
\hline Family/species & $\begin{array}{l}\text { Main local } \\
\text { name }\end{array}$ & $\begin{array}{l}\text { Voucher no. in ERCB } \\
\text { and conservation status }\end{array}$ & Used parts & Ways of use \\
\hline \multicolumn{5}{|l|}{ Acoraceae } \\
\hline Acorus calamus L. & $\begin{array}{l}\text { Khnkegheg, } \\
\text { baghshtak }\end{array}$ & Armenian Red List & Rhizomes & $\begin{array}{l}\text { MED: Tincture for digestive disorders, } \\
\text { respiratory system diseases, } \\
\text { inflammatory skin diseases. Decoction } \\
\text { against anaemia, diseases of the } \\
\text { nervous system, as a lotion against hair } \\
\text { loss. Tea for appetite. }\end{array}$ \\
\hline
\end{tabular}

Alliaceae

Allium atroviolaceum Boiss.

Karmrasokhuk 13552

Aerial parts, bulb

Allium rotundum $\mathrm{L}$

Dashtaskhtor

13524

Allium victorialis $\mathrm{L}$.

Ghandzil

13484

Havakatar

Amaranthus retroflexus $\mathrm{L}$.

Atriplex prostrata subsp.

calotheca (Rafn) M.A.Gust.

[syn. Atriplex hastata L.]

Atriplex sagittata Borkh.

[syn. Atriplex nitens Schkuhr]

Mokhrateluk, tal 13559

Teluk

Apiaceae

Angelica tatianae Bordz.

Bokhni, kekh

Anthriscus nemorosa (Bieb.) Spreng.

Khrkhnduk, trtruk

Astrodaucus orientalis (L.) Drude

Carum carvi L.

Chaerophyllum aureum $L$.

Chaerophyllum bulbosum L.

Daucus carota L.
Mandak, astghagazar

Qimon, zire, hayots chaman

Shushanbanjar, 13490 ghmi, mandak

Shushanbanjar, 13461 mandak

Gjazruk
Young leaves and stems

Young leaves and stems

Young leaves and stems

Young leaves and stems

Leafstalk, leaves and stems

Young stems, leaves

Young leaves and stems

Seeds

Young leaves and stems, roots

Young leaves and stems, bulbous roots

Young leaves and stems, seeds
CUL: Salads, lacto-fermented, spice for dishes and cheese. MED: Fresh leaves for gum pain from the growth of baby teeth, as a multivitamin, fresh bulbs with honey or sugar for respiratory system diseases, baked bulbs for cough.

CUL: Salads, lacto-fermented, spice for dishes and cheese. MED: Fresh leaves for gum pain from the growth of baby teeth, as a multivitamin.

CUL: Salads, lacto-fermented, spice for dishes and cheese. MED: Fresh leaves for gum pain from the growth of baby teeth, as a multivitamin.

CUL: Fried. MED: Infusion for diarrhoea, boiled herb for constipation.

CUL: Salads, lacto-fermented, fried, filling for pies.

CUL: Salads, lacto-fermented, fried, filling for pies.

CUL: Fried. MED: Fresh juice used for stomach and intestine diseases, for the treatment of headaches and constipation.

CUL: Salads, lacto-fermented. MED: Infusion for digestive disorders and respiratory system diseases.

CUL: Lacto-fermented. MED: Infusion of leaves for digestive disorders and the treatment of skin diseases.

CUL: Lacto-fermented, fried. MED: Infusion used in digestive disorders.

CUL: Spice for dishes, pickles and sujukh (spicy sausage). MED: Infusion for digestive disorders.

CUL: Aerial parts lacto-fermented, fried. MED: Infusion of roots for digestive disorders.

CUL: Lacto-fermented, fried. MED: Infusion of bulbous roots for digestive disorders.

CUL: Fried. MED: Infusion of seeds for digestive disorders. 
Table 3 Wild plants sold in Yerevan's markets (Continued)

\begin{tabular}{|c|c|c|c|c|}
\hline Family/species & $\begin{array}{l}\text { Main local } \\
\text { name }\end{array}$ & $\begin{array}{l}\text { Voucher no. in ERCB } \\
\text { and conservation status }\end{array}$ & Used parts & Ways of use \\
\hline Falcaria vulgaris Bernh. & Sibekh & 13476 & $\begin{array}{l}\text { Young leaves and } \\
\text { stems, roots }\end{array}$ & $\begin{array}{l}\text { CUL: Lacto-fermented, fried. MED: } \\
\text { Infusion of leaves to stop bleeding } \\
\text { caused by tuberculosis, boiled root } \\
\text { with honey and wine for strengthening. }\end{array}$ \\
\hline Ferula szowitziana DC. & Nardes, bogh & Armenian Red List & Leafstalk, gum & $\begin{array}{l}\text { CUL: Lacto-fermented, fried. MED: } \\
\text { Infusion against neuritis, epilepsy, kidney } \\
\text { stone disease, gum used for digestive } \\
\text { disorders and respiratory system } \\
\text { diseases. }\end{array}$ \\
\hline Ferulago setifolia K.Koch & $\begin{array}{l}\text { Nardesuk, } \\
\text { pirvaz }\end{array}$ & 13564 & $\begin{array}{l}\text { Young leaves, stems, } \\
\text { flowers }\end{array}$ & CUL: Lacto-fermented, fried, soups. \\
\hline Foeniculum vulgare Mill. & Horom samit & 13549 & Young stems, seeds & $\begin{array}{l}\text { CUL: Fried, used as spice for dishes, } \\
\text { pickles, liqueur, candy, sauce. MED: } \\
\text { Infusion used in digestive disorders, as a } \\
\text { choleretic, carminative and spasmolytic } \\
\text { agent. }\end{array}$ \\
\hline Heracleum antasiaticum Manden & Bldrghan, qegh & 13566 & $\begin{array}{l}\text { Young stems, leafstalk, } \\
\text { boots }\end{array}$ & $\begin{array}{l}\text { CUL: Lacto-fermented. MED: Decoction } \\
\text { of herb used against liver and } \\
\text { gallbladder diseases. }\end{array}$ \\
\hline Heracleum chorodanum (Hoffm.) DC. & Bldrghan & & Young stems, leafstalk & CUL: Lacto-fermented \\
\hline $\begin{array}{l}\text { Heracleum trachyloma Fisch. and } \\
\text { C.A.Mey. }\end{array}$ & Bldrghan & 13550 & Young stems, leafstalk & CUL: Lacto-fermented \\
\hline $\begin{array}{l}\text { Bilacunaria microcarpa (M.Bieb.) } \\
\text { Pimenov and V.N.Tikhom. } \\
\text { [syn. Hippomarathrum microcarpum } \\
\text { Petrov] }\end{array}$ & Bokhi, pekhi & 13562 & $\begin{array}{l}\text { Young stems, leafstalk, } \\
\text { boots }\end{array}$ & $\begin{array}{l}\text { CUL: Lacto-fermented, fresh juice used } \\
\text { for stomach diseases, as hypoglycaemic } \\
\text { agent. }\end{array}$ \\
\hline Pimpinella saxifraga $\mathrm{L}$. & $\begin{array}{l}\text { Anison, } \\
\text { qoshkhot }\end{array}$ & 13551 & Seeds & $\begin{array}{l}\text { CUL: Spice for pilaf. MED: Tincture for } \\
\text { digestive disorders, respiratory system } \\
\text { diseases. }\end{array}$ \\
\hline Prangos ferulacea (L.) Lindl. & Poli, geli bokhi & 13557 & Young leaves & CUL: Lacto-fermented, fried. \\
\hline
\end{tabular}

Araceae

Arum orientale M.Bieb. Nvik, spitak 13489

banjar
Dried and then boiled leaves and rhizomes
CUL: Soups and sauce from dried and then boiled leaves, flour from dried and boiled rhizomes. MED: Powder from dried rhizomes against inflammatory skin diseases, infusion of rhizomes as inflammatory agent for digestive disorders, respiratory system diseases, and for use as an anthelmintic drug.

\section{Asparagaceae}

Asparagus officinalis $\mathrm{L}$.

Asparagus verticillatus $\mathrm{L}$.

Tsnepak tsnebek

Tsnepak, tsnebek

Young stems

Young stems

$\begin{array}{lll}\text { Ornithogalum hajastanum Agapova } & \text { Spitak banjar } & 13469 \\ \text { Ornithogalum montanum Cirillo } & \text { Khnjloz } & 13470 \\ & & \\ \text { Polygonatum glaberrimum K.Koch } & \text { Sindrik } & 13560\end{array}$

Dried leaves

Young leaves and bulbs

Young leaves and stems, rhizomes
CUL: Salads, fried with eggs. MED: Used as a multivitamin, boiled herb for constipation, infusion as hypoglycaemic and diuretic agent, against inflammatory diseases of the kidneys and bladder.

CUL: Salads, fried with eggs. MED: Used as a multivitamin, boiled herb for constipation, as hypoglycaemic and diuretic agent, against inflammatory diseases of kidneys and bladder.

CUL: Soup, fried.

CUL: Lacto-fermented, fried.

CUL: Salads, lacto-fermented, fried. MED: Fresh rhizomes and leaves used in cosmetology and against skin diseases, boiled leaves and tincture as an antidiabetic remedy. 
Table 3 Wild plants sold in Yerevan's markets (Continued)

\begin{tabular}{|c|c|c|c|c|}
\hline Family/species & $\begin{array}{l}\text { Main local } \\
\text { name }\end{array}$ & $\begin{array}{l}\text { Voucher no. in ERCB } \\
\text { and conservation status }\end{array}$ & Used parts & Ways of use \\
\hline Polygonatum multiflorum (L.) All. & Sindrik & & $\begin{array}{l}\text { Young leaves and } \\
\text { stems, rhizomes }\end{array}$ & $\begin{array}{l}\text { CUL: Salads, lacto-fermented, fried. MED: } \\
\text { Fresh rhizomes and leaves used in } \\
\text { cosmetology and against skin diseases, } \\
\text { boiled leaves and tincture as an } \\
\text { antidiabetic remedy. }\end{array}$ \\
\hline Polygonatum orientale Desf. & Sindrik & 13506 & $\begin{array}{l}\text { Young leaves and } \\
\text { stems, rhizomes }\end{array}$ & $\begin{array}{l}\text { CUL: Salads, lacto-fermented, fried. MED: } \\
\text { Fresh rhizomes and leaves used in } \\
\text { cosmetology and against skin diseases, } \\
\text { boiled leaves and tincture as an } \\
\text { antidiabetic remedy. }\end{array}$ \\
\hline Puschkinia scilloides Adams & Alayaz & 13532 & Fresh and dried leaves & CUL: Fried, cooked in soup with lentils. \\
\hline \multicolumn{5}{|l|}{ Asphodelaceae } \\
\hline Eremurus spectabilis M.Bieb. & Shresh, shresht & 13569 & Young leaves, roots & $\begin{array}{l}\text { CUL: Salads, fried, lacto-fermented. MED: } \\
\text { Infusion of leaves for digestive disorders. } \\
\text { Powder from rhizomes used against skin } \\
\text { abscesses and cysts. }\end{array}$ \\
\hline
\end{tabular}

\section{Asteraceae}

Achillea millefolium L.

Achillea tenuifolia Lam.

Arctium tomentosum Mill.

Kratuk

13572

Artemisia absinthium L.

Artemisia austriaca Jacq.

Oshindr

Oshindr
Young leaves and stems, flowers, dried herb

Young leaves and stems, flowers, dried herb

Young leaves, stems, fresh and dried roots

oung leaves, stems, fresh and dried roots

Young leaves, herb

oung leaves, herb

Artemisia fragrans Willd.

Oshindr
CUL: Fresh leaves and fried stems, dried herb as spices for fatty meat, liqueur and tea. MED: Infusion of herbs for digestive disorders and used as appetitive agent against uterine bleeding, as diuretic agent.

CUL: Fresh leaves and stems fried, dried herb as spices, for liqueur and tea. MED: Infusion of herbs for digestive disorders and as appetitive agent, against uterine bleeding, as diuretic agent.

CUL: Young leaves, stems and fresh roots for salads, soup, powder of dried root as coffee. MED: Infusion of roots as antipyretic, diuretic and hypoglycaemic agents, as lotion for hair growth, powder from leaves used against skin abscesses and sores.

CUL: Young leaves, stems and fresh roots for salads, soup. MED: Infusion of roots as antipyretic, diuretic and hypoglycaemic agents, as lotion for hairs growth, powder from leaves used against skin abscesses and as wound healing agent.

CUL: As spices for liqueur and vodka. Dried herbs as mothproofing agent. MED: Infusion of herbs for digestive disorders and as appetitive agent, as anti-inflammatory agent against liver, gallbladder and pancreas diseases, as anthelmintic drug. REP.

CUL: As spices for liqueur and vodka. Dried herbs as mothproofing agent. MED: Infusion and tincture of herbs for digestive disorders and as appetitive agent, as anti-inflammatory agent against liver, gallbladder and pancreas diseases, as anthelmintic drug. REP: Against moths.

CUL: As spices for liqueur and vodka. Dried herbs as mothproofing agent, decorative plant and grass for good luck. MED: Infusion and tincture of 
Table 3 Wild plants sold in Yerevan's markets (Continued)

\begin{tabular}{llll}
\hline Family/species & $\begin{array}{l}\text { Main local } \\
\text { name }\end{array}$ & $\begin{array}{l}\text { Voucher no. in ERCB } \\
\text { and conservation status }\end{array}$ & Used parts \\
\hline & & & \\
Artemisia tournefortiana Rchb. & Oshindr & 13468 & Young leaves, herb
\end{tabular}

Ways of use

herbs for digestive disorders and as appetitive agent, as anti-inflammatory agent for treatment of liver, gallbladder and pancreas diseases as anthelmintic drug. DEC. REP: Against moths. MAGIC. 13468

Oshindr

13467

Artemisia vulgaris L.

Cyanus segetum Hill. [syn. Centaurea cyanus L.]

Cichorium intybus L.

Helichrysum rubicundum (K.Koch) Bornm.

Helichrysum plicatum DC.

Inula helenium L.

Lactuca serriola L.

Leontodon hispidus L.

Leucanthemum vulgare (Vaill.)Lam.

Picris hieracioides Sibth. and Sm.

Podospermum laciniatum (L.) DC.

Senecio leucanthemifolius subsp.

vernalis (Waldst. and Kit.) Greuter

[syn. Senecio vernalis Waldst. and Kit.]
Terepuk kapuyt 13498

Tchartchatuk,

Egherd,

Antaram,

anmer tsaghik

Antaram,

anmer tsaghik

Heghinei khot, kghmugh

Hazar, kathnuk, 13477 radika

Aryutsatam,

radika

Spitakatsaghik,

eritsuk

13139

Darnitch

Sermnotuk,

$\operatorname{sind} z$

Halevoruk

13471
CUL: As spices for liqueur and vodka. Dried herbs as mothproofing agent. MED: Infusion and tincture of herbs for digestive disorders and as appetitive agent, as anti-inflammatory agent against liver, gallbladder and pancreas diseases, as anthelmintic drug. REP: Against moths.

Young leaves, herb

As spices for liqueur and vodka. Dried herbs as mothproofing agent. MED: Infusion and tincture of herbs for digestive disorders and as appetitive agent, as anti-inflammatory agent against liver, gallbladder and pancreas diseases, as anthelmintic drug. REP: Against moths.

Flowers

Leaves, stems, roots

CUL: Spice for tea. MED: Decoction for rinsing inflamed eyes. DEC.

CUL: Powder of dried root as coffee or tea. MED: Infusion for digestive disorders and as hypoglycaemic agent, tincture of roots as wound healing agent against snake and scorpion bites.

CUL: Herbal mix for tea. MED: Infusion against liver and gallbladder diseases, as choleretic and appetitive agents. DEC.

Flowers

Roots and rhizomes

CUL: Herbal mix for tea. MED: Infusion against liver and gallbladder diseases, as choleretic and appetitive agents. DEC.

MED: Decoction as anti-inflammatory, expectorant agent and against respiratory system diseases, as an antipyretic, for digestive disorders and as appetitive agent. Tea with honey against coughs. Decoction or ointment as wound healing agent. DEC.

Young basal leaves

CUL: Salads, in spring as a multivitamin. MED: Infusion against cough, respiratory system diseases, diseases of nervous system. Powder of dried leaves as wound healing agent.

Young basal leaves

CUL: Salads. MED: Infusion against gallbladder diseases, for teething pain. DEC.

Flowers

Young leaves and stems

Young leaves, roots

Young leaves

MED: Infusion and tea mistaken for chamomile. DEC.

CUL: Salads. MED: Boiled leaves for constipation, powder of dried leaves against skin abscesses.

CUL: Salads, fried.

CUL: Fried. MED: Boiled leaves for constipation, as diuretic and choleretic agent. 
Table 3 Wild plants sold in Yerevan's markets (Continued)

\begin{tabular}{|c|c|c|c|c|}
\hline Family/species & $\begin{array}{l}\text { Main local } \\
\text { name }\end{array}$ & $\begin{array}{l}\text { Voucher no. in ERCB } \\
\text { and conservation status }\end{array}$ & Used parts & Ways of use \\
\hline $\begin{array}{l}\text { Tanacetum polycephalum subsp. } \\
\text { argyrophyllum (K.Koch) Podlech [syn. } \\
\text { Tanacetum argyrophyllum (K.Koch) } \\
\text { Tzvel.] }\end{array}$ & $\begin{array}{l}\text { Meghvamushk, } \\
\text { Ivatsaghik }\end{array}$ & 13501 & Flowers & $\begin{array}{l}\text { CUL: Spice for pickles and liqueur. } \\
\text { Infusion against nephritis. }\end{array}$ \\
\hline Tanacetum vulgare $\mathrm{L}$. & $\begin{array}{l}\text { Tarkavan, } \\
\text { meghvamushk, } \\
\text { Ivatsaghik }\end{array}$ & 13575 & Flowers, herb & $\begin{array}{l}\text { CUL: Spice for pickles and liqueur. MED: } \\
\text { Herb as anthelmintic agent, against } \\
\text { liver, gallbladder, stomach and intestine } \\
\text { diseases. }\end{array}$ \\
\hline $\begin{array}{l}\text { Taraxacum bessarabicum (Hornem.) } \\
\text { Hand. Mazz. }\end{array}$ & Khatutik, radika & 13576 & Young leaves, roots & $\begin{array}{l}\text { CUL: Salads, fried. MED: Infusion against } \\
\text { digestive disorders, as a diuretic, } \\
\text { choleretic, appetitive agent. Fresh leaves } \\
\text { against skin diseases and abscesses. } \\
\text { Juice of fresh leaves as a multivitamin } \\
\text { and against anaemia. }\end{array}$ \\
\hline $\begin{array}{l}\text { Taraxacum sonchoides (D.Don) } \\
\text { Sch.Bip. [syn. Taraxacum montanum } \\
\text { (C.A. Mey.) DC.] }\end{array}$ & Khatutik, radika & & Young leaves, roots & $\begin{array}{l}\text { CUL: Salads, fried. MED: Infusion against } \\
\text { digestive disorders, as diuretic, } \\
\text { choleretic, appetitive agent. Fresh leaves } \\
\text { against skin diseases and abscesses. } \\
\text { Juice of fresh leaves as a multivitamin } \\
\text { and against anaemia. }\end{array}$ \\
\hline $\begin{array}{l}\text { Taraxacum officinale (L.) Weber ex } \\
\text { F.H.Wigg. }\end{array}$ & Khatutik, radika & 13475 & Young leaves, roots & $\begin{array}{l}\text { CUL: Salads, fried. MED: Infusion against } \\
\text { digestive disorders, as diuretic, } \\
\text { choleretic, appetitive agent. Fresh leaves } \\
\text { against skin diseases and abscesses. } \\
\text { Juice of fresh leaves as a multivitamin } \\
\text { and against anaemia. Latex used against } \\
\text { warts. }\end{array}$ \\
\hline Tragopogon coloratus C.A. Mey. & $\begin{array}{l}\text { Sindz, } \\
\text { qoshmoruk }\end{array}$ & 13514 & $\begin{array}{l}\text { Young leaves and } \\
\text { stems }\end{array}$ & $\begin{array}{l}\text { CUL: Salads, fried, chewing gum from } \\
\text { latex. MED: Latex used to stop bleeding } \\
\text { and headaches. }\end{array}$ \\
\hline Tragopogon graminifolius DC. & $\begin{array}{l}\text { Sindz, } \\
\text { qoshmoruk }\end{array}$ & & $\begin{array}{l}\text { Young leaves and } \\
\text { stems }\end{array}$ & $\begin{array}{l}\text { CUL: Salads, fried, chewing gum from } \\
\text { latex. MED: Latex used to stop bleeding } \\
\text { and headaches. }\end{array}$ \\
\hline $\begin{array}{l}\text { Tragopogon dubius Scop. [syn. } \\
\text { Tragopogon major Jacq.] }\end{array}$ & $\begin{array}{l}\text { Sindz, } \\
\text { qoshmoruk }\end{array}$ & & $\begin{array}{l}\text { Young leaves and } \\
\text { stems }\end{array}$ & $\begin{array}{l}\text { CUL: Salads, fried, chewing gum from } \\
\text { latex. }\end{array}$ \\
\hline Tragopogon pterocarpus DC. & $\begin{array}{l}\text { Sindz, } \\
\text { qoshmoruk }\end{array}$ & & $\begin{array}{l}\text { Young leaves and } \\
\text { stems }\end{array}$ & $\begin{array}{l}\text { CUL: Salads, fried, chewing gum from } \\
\text { latex. MED: Use to strengthen immunity, } \\
\text { to stop bleeding, against stomach and } \\
\text { intestine diseases. }\end{array}$ \\
\hline $\begin{array}{l}\text { Tragopogon reticulatus Boiss. and } \mathrm{A} \text {. } \\
\text { Huet }\end{array}$ & $\begin{array}{l}\text { Sindz, } \\
\text { qoshmoruk }\end{array}$ & 13513 & $\begin{array}{l}\text { Young leaves and } \\
\text { stems }\end{array}$ & $\begin{array}{l}\text { CUL: Salads, fried, chewing gum from } \\
\text { latex. }\end{array}$ \\
\hline Tragopogon serotinus Sosn. & $\begin{array}{l}\text { Sindz, } \\
\text { qoshmoruk }\end{array}$ & & $\begin{array}{l}\text { Young leaves and } \\
\text { stems }\end{array}$ & $\begin{array}{l}\text { CUL: Salads, fried, chewing gum from } \\
\text { latex. MED: Latex used to stop of } \\
\text { bleeding, against headaches. }\end{array}$ \\
\hline Tussilago farfara $\mathrm{L}$. & $\begin{array}{l}\text { Tatrak, } \\
\text { khochkorik, } \\
\text { hazi degh }\end{array}$ & 13502 & Leaves & $\begin{array}{l}\text { MED: Infusion against respiratory system } \\
\text { diseases, cough, as an antipyretic and } \\
\text { expectorant agent. }\end{array}$ \\
\hline \multicolumn{5}{|l|}{ Berberidaceae } \\
\hline Berberis vulgaris $\mathrm{L}$. & $\begin{array}{l}\text { Tsoreni, } \\
\text { ktsokhur }\end{array}$ & 13485 & $\begin{array}{l}\text { Fresh and dried fruits, } \\
\text { bark of roots and } \\
\text { stems, wood }\end{array}$ & $\begin{array}{l}\text { CUL: Jam and liqueur from ripe fruits, as } \\
\text { spice for dishes and tea. WOOD: For } \\
\text { handicrafts. MED: Infusion of bark } \\
\text { against gallbladder, stomach, intestines } \\
\text { and eye diseases, against skin abscesses. } \\
\text { DEC. }\end{array}$ \\
\hline $\begin{array}{l}\text { Berberis orientalis C.K. Schneid. [this } \\
\text { species is now included in B. vulgaris } \\
\text { according to the Plant List but } \\
\text { regarded as separate in Armenian } \\
\text { floras] }\end{array}$ & $\begin{array}{l}\text { Tsoreni, } \\
\text { ktsokhur }\end{array}$ & 13574 & $\begin{array}{l}\text { Fresh and dried fruits, } \\
\text { wood }\end{array}$ & $\begin{array}{l}\text { CUL: Jam and liqueur from ripe fruits, as } \\
\text { spice for dishes and tea. WOOD: For } \\
\text { handicrafts. MED: Infusion of bark } \\
\text { against gallbladder, stomach, intestine } \\
\text { and eye diseases, against skin abscesses. } \\
\text { DEC. }\end{array}$ \\
\hline
\end{tabular}


Table 3 Wild plants sold in Yerevan's markets (Continued)

\begin{tabular}{llll}
\hline Family/species & $\begin{array}{l}\text { Main local } \\
\text { name }\end{array}$ & $\begin{array}{l}\text { Voucher no. in ERCB } \\
\text { and conservation status }\end{array}$ & $\begin{array}{l}\text { Used parts } \\
\text { Betulaceae }\end{array}$ \\
$\begin{array}{lll}\text { Corylus avellana L. } \\
\text { Tkhleni, }\end{array}$ & 13567 & $\begin{array}{l}\text { Fresh, dried and } \\
\text { roasted nuts, leaves, } \\
\text { nutshell, wood }\end{array}$ & $\begin{array}{l}\text { CUL: Sweets and candy, nuts. WOOD: } \\
\text { For handicrafts. MED: Tea from leaves as } \\
\text { diuretic, antipyretic, for boosting the } \\
\text { immune system, infusion of leaves } \\
\text { against kidney and intestines diseases, } \\
\text { as anti-inflammatory agent, ash of } \\
\text { nutshell as wound healing agent. Nuts } \\
\text { for sexual potency. }\end{array}$ \\
\end{tabular}

\section{Brassicaceae}

Barbarea vulgaris R.Br.

Capsella bursa-pastoris (L.) Medik.

Tstapashar

13474

Lepidium draba L.

Lepidium latifolium L.

Rorippa islandica (Oeder) Borbás

Cannabaceae

Cannabis sativa $\mathrm{L}$.

\section{Capparaceae}

Capparis spinosa $\mathrm{L}$.
Khruk, paron banjar

Ghji

Ktsvich, paron

banjar

Kaneph

13558

Kanap, otsi dzmeruk

\section{Caprifoliaceae}

Cephalaria gigantea (Ledeb.) Bobrov

Ghantapa, jivan

13528

Valeriana officinalis $\mathrm{L}$.

Katvakhot

Viburnum opulus L.

Brnchi

13487

\section{Caryophyllaceae}

Stellaria media (L.) Cyr.

Tchrtchruk

Young and dried leaves, herb

Young leaves

Young leaves

Young leaves

Young leaves

Seeds

Young flower bud fruits, roots

Fresh and dried flowers

Dried roots, rhizomes

Fresh and dried fruits

Young leaves and stems

Blossoming shoots
CUL: Salads, fried. MED: Infusion of herb as diuretic, immunity booster, antiinflammatory agent.

CUL: Salads, fried. MED: Infusion of herbs to prevent bleeding of the uterus, as diuretic, choleretic and wound healing agent. Juice of fresh herbs against kidney, liver and gallbladder diseases.

CUL: Fried with eggs.

CUL: Fried with eggs. MED: Infusion of leaves against skin diseases, nervous disorders and teething pain.

CUL: Salads.

CUL: In a roasted seed mix of wheat, hemp and flax (aghandz). MED: Powdered seeds with water for boosting the immune system and enhancing sexual potency.

CUL: Flower buds used for pickles and as a spice. MED: Infusion of roots used for liver diseases, as hypoglycaemic agent. Compress from pulp of fruits and roots against headaches and joint and muscle pains.

CUL: Tea. MED: Infusion as an antipyretic, against colds and coughs, lotion against skin diseases.

MED: Infusion or decoction used for anxiety and stress, for sleep disorders.

CUL: Juice, jam, liqueur, sweets and candy. Fresh and dried fruits used as a multivitamin, diuretic and immune system booster.

CUL: Salads, filling for pies (zhingyalov hats).

DEC: Decoration only.
Merendera trigyna Woronow 
Table 3 Wild plants sold in Yerevan's markets (Continued)

\begin{tabular}{|c|c|c|c|c|}
\hline Family/species & $\begin{array}{l}\text { Main local } \\
\text { name }\end{array}$ & $\begin{array}{l}\text { Voucher no. in ERCB } \\
\text { and conservation status }\end{array}$ & Used parts & Ways of use \\
\hline \multicolumn{5}{|l|}{ Cornaceae } \\
\hline Cornus mas L. & Hon & 13204 & $\begin{array}{l}\text { Fresh and dried fruits, } \\
\text { pips of fruits, wood }\end{array}$ & $\begin{array}{l}\text { CUL: Juice, jam, compote, dry pastille } \\
\text { (ttu lavash), liqueur, lacto-fermented. } \\
\text { WOOD: For buttons, pips of fruits for } \\
\text { bijouterie and chaplets. MED: Jam with } \\
\text { tea used to treat digestive disorders, } \\
\text { diarrhoea and colds. DEC. }\end{array}$ \\
\hline \multicolumn{5}{|l|}{ Cucurbitaceae } \\
\hline Bryonia alba L. & $\begin{array}{l}\text { Loshtak, } \\
\text { arjakhaghogh }\end{array}$ & 13527 & Dried roots & $\begin{array}{l}\text { MED: Infusion of roots against stomach } \\
\text { diseases, haemorrhoids, as immune } \\
\text { system booster and enhancer of sexual } \\
\text { potency. }\end{array}$ \\
\hline \multicolumn{5}{|l|}{ Elaeagnaceae } \\
\hline $\begin{array}{l}\text { Elaeagnus angustifolia L. [including } \\
\text { Elaeagnus orientalis L.] }\end{array}$ & Phshateni & 13525 & Fresh and dried fruits & $\begin{array}{l}\text { CUL: Flour, sweets. MED: Fruits and fruit } \\
\text { infusions used to treat digestive } \\
\text { disorders and diarrhoea. DEC. Whole } \\
\text { branches with fruits for decoration. }\end{array}$ \\
\hline Elaeagnus rhamnoides (L.) A.Nelson & Chichkhan & 13531 & $\begin{array}{l}\text { Fresh and dried fruits, } \\
\text { wood }\end{array}$ & $\begin{array}{l}\text { CUL: Juice, jam, liqueur. MED: Fruits as a } \\
\text { multivitamin. Oil of fruits in } \\
\text { cosmetology and stomatology for gum } \\
\text { disease, as a wound healing agent } \\
\text { against skin diseases. DEC. Whole } \\
\text { branches with fruits for decoration. } \\
\text { WOOD. }\end{array}$ \\
\hline
\end{tabular}

Equisetaceae

Equisetum arvense $\mathrm{L}$.

Dziadzet

Herb of green shoot

MED: Infusion of herb as diuretic agent against kidney, bladder, inflammatory and kidney stone diseases.

\section{Ericaceae}

Vaccinium myrtillus $\mathrm{L}$.

Hapalaseni

Fresh and dried berries

Fabaceae

Glycyrrhiza glabra L.

Matutak

Roots, rhizomes

\section{Lathyrus pratensis $\mathrm{L}$.}

Tchpruk

Lathyrus tuberosus $\mathrm{L}$.

Tchpruk

13542

Melilotus officinalis (L.) Pall.

Isharvuyt

13448

Trifolium pratense $\mathrm{L}$.

Ereqnuk

Young leaves and

stems

Tuberous roots

Herbs

Trifolium repens $\mathrm{L}$.

Ereqnuk

13499

Flowers

Herbs, flowers

Fagaceae

Castanea sativa Mill.

Shaganak

Nuts, wood
CUL: Juice, jam, liqueur. MED: Berries as a multivitamin, tea from berries for diarrhoea, eye diseases, and improving eyesight.

CUL: Sweets. MED: Infusion of roots or powder in bread against colds and coughs, against stomach and intestine diseases.

CUL: Salad, fried.

CUL: Boiled.

CUL: Tea. MED: Infusion as a diuretic, against hypertension, diseases of the female reproductive system, fresh juice used for inflammatory diseases of ears and eyes.

CUL: Tea. MED: Infusion as a diuretic, against coughs and diseases of the female reproductive system and the stomach.

CUL: Tea.

CUL: Fresh, boiled and roasted nuts. Handicrafts. MED: Boiled fruits to strengthen, against lungs and bladder diseases. WOOD. 
Table 3 Wild plants sold in Yerevan's markets (Continued)

\begin{tabular}{|c|c|c|c|c|}
\hline Family/species & $\begin{array}{l}\text { Main local } \\
\text { name }\end{array}$ & $\begin{array}{l}\text { Voucher no. in ERCB } \\
\text { and conservation status }\end{array}$ & Used parts & Ways of use \\
\hline Fagus orientalis Lipsky & Hatchareni & 13459 & Nuts, wood & $\begin{array}{l}\text { CUL: Fresh and roasted nuts. } \\
\text { Handicrafts, parquet, door, furniture. } \\
\text { WOOD. }\end{array}$ \\
\hline
\end{tabular}

\section{Grossulariaceae}

Ribes uva-crispa L. [syn. Grossularia reclinata (L.) Mill.]

Ribes armenum Pojark.

Ribes petraeum Wulfen [syn. Ribes biebersteinii Berland. ex DC.]

Ribes alpinum $\mathrm{L}$.

Hagharjeni

Hagharjeni

Hagharjeni

Armenian Red List

Srohund,

arevqurik

Hypericum perforatum L.

Juglandaceae
Juglans regia $\mathrm{L}$.

Y'nkuzeni

Lamiaceae

Mentha longifolia (L.) Huds. Daghd

Origanum vulgare L.

Salvia hydrangea DC. ex Benth.
Daghdz

Aryutsagi

13466

13494

Khnkatsaghik sevakhot

Eghespak

13577
Fresh and dried fruits fermented. MED: Berries as a multivitamin, berry tea against colds and as a diuretic agent.

Fresh and dried fruits, leaves

Fresh and dried fruits, leaves

Fresh and dried fruits, leaves

CUL: Berries for juice, jam, liqueur, lactofermented. Leaves as a tea. MED: Berries as a multivitamin, berry tea against colds, as a diuretic and an antipyretic agent.

CUL: Berries for juice, jam, liqueur, lactofermented. Leaves as a tea. MED: Berries as a multivitamin, tea of berries against colds, as a diuretic and antipyretic agent.

CUL: Berries for juice, jam, liqueur, lactofermented. Leaves as a tea. MED: Berries as a multivitamin, berry tea against colds, as a diuretic and antipyretic agent.

Dried herbs, oil

CUL: Tea. MED: Infusion against digestive disorders and stomach diseases. Oil against gastric ulcers and skin diseases and for use in cosmetology.

Young, fresh walnut, dried walnuts kernels, dried walnuts partitions, oil, leaves, wood

CUL: Fresh walnuts for jam, dried walnut kernels as sweets, candy, ingredient of savoury dishes and source of edible oil. WOOD: For musical instruments (tar, qyamancha), handicrafts, parquet, door, furniture. REP: Leaves. MED: Tincture of fresh walnuts against hypothyroidism and digestive disorders. Dried walnut kernels with honey as a multivitamin for strengthening immunity, as a sexual potency enhancer and anthelmintic agent. Infusion of dried walnut partitions against headaches, sore throats, diarrhoea, and used as an anthelmintic agent. Oil as an ointment in cosmetology. DEC.

MED: Tincture and infusion for heart diseases.

CUL: Tea, drink, cocktails, as spice for soups, meat dishes, sweets and cheese. MED: Infusion against heartache, headache, digestive disorders and colds.

CUL: Tea, spice for meat dishes. MED: Infusion against digestive disorders, colds, coughs, and respiratory system diseases. Oil in cosmetology.

CUL: Tea. 
Table 3 Wild plants sold in Yerevan's markets (Continued)

\begin{tabular}{|c|c|c|c|c|}
\hline Family/species & $\begin{array}{l}\text { Main local } \\
\text { name }\end{array}$ & $\begin{array}{l}\text { Voucher no. in ERCB } \\
\text { and conservation status }\end{array}$ & Used parts & Ways of use \\
\hline Salvia sclarea L. & Eghespak & 13488 & Herbs & $\begin{array}{l}\text { CUL: Tea. MED: Infusion against teething } \\
\text { pain, sore throat and gum disease. Oil in } \\
\text { cosmetology. }\end{array}$ \\
\hline Salvia verticillata $L$. & Eghespak & 13217 & Herbs & $\begin{array}{l}\text { CUL: Tea. MED: Infusion against teething } \\
\text { pain, sore throat and gum disease. }\end{array}$ \\
\hline Stachys palustris L. & Abeghakhot & 13561 & Herbs & $\begin{array}{l}\text { MED: Infusion or tincture for the } \\
\text { treatment of the female reproductive } \\
\text { system and irregular periods. }\end{array}$ \\
\hline Teucrium polium L. & Mariamakhot & 13252 & Herbs & $\begin{array}{l}\text { MED: Infusion for the treatment of the } \\
\text { female reproductive system and } \\
\text { irregular periods, digestive disorders, } \\
\text { stomach and intestines diseases, as } \\
\text { eyewash agent. }\end{array}$ \\
\hline Thymus collinus M.Bieb. & Urts, khur & 13508 & $\begin{array}{l}\text { Fresh and dried } \\
\text { leaves, herbs }\end{array}$ & $\begin{array}{l}\text { CUL: Tea, as a spice for soups, meat } \\
\text { dishes and cheese. MED: Infusion } \\
\text { against the digestive disorders, stomach, } \\
\text { liver and intestines diseases, colds, } \\
\text { respiratory system diseases, } \\
\text { hypertension and heartache, as } \\
\text { expectorant and antibacterial agent. Oil } \\
\text { in cosmetology. }\end{array}$ \\
\hline $\begin{array}{l}\text { Thymus kotschyanus Boiss. and } \\
\text { Hohen. }\end{array}$ & Urts, khur & 13441 & $\begin{array}{l}\text { Fresh and dried } \\
\text { leaves, herbs }\end{array}$ & $\begin{array}{l}\text { CUL: Tea, as spice for soups, meat } \\
\text { dishes and cheese. MED: Infusion } \\
\text { against the digestive disorders, stomach, } \\
\text { liver and intestine diseases, colds, } \\
\text { respiratory system diseases, } \\
\text { hypertension and heartache, as } \\
\text { expectorant and antibacterial agent. Oil } \\
\text { in cosmetology. }\end{array}$ \\
\hline Thymus rariflorus K.Koch & Urts, khur & 13503 & $\begin{array}{l}\text { Fresh and dried } \\
\text { leaves, herbs }\end{array}$ & $\begin{array}{l}\text { CUL: Tea, as spice for soups, meat } \\
\text { dishes and cheese. MED: Infusion } \\
\text { against digestive disorders, stomach, } \\
\text { liver and intestine diseases, colds, } \\
\text { respiratory system diseases, } \\
\text { hypertension and heartache, as } \\
\text { expectorant and antibacterial agent. Oil } \\
\text { in cosmetology. }\end{array}$ \\
\hline T. transcaucasicus Ronniger & Urts, khur & 13545 & $\begin{array}{l}\text { Fresh and dried } \\
\text { leaves, herbs }\end{array}$ & $\begin{array}{l}\text { CUL: Tea, as spice for soups, meat } \\
\text { dishes and cheese. MED: Infusion } \\
\text { against digestive disorders, stomach, } \\
\text { liver and intestine diseases, colds, } \\
\text { respiratory system diseases, } \\
\text { hypertension and heartache, as } \\
\text { expectorant and antibacterial agent. Oil } \\
\text { in cosmetology. }\end{array}$ \\
\hline Ziziphora clinopodioides Lam. & $\begin{array}{l}\text { Urtsadaghdz, } \\
\text { limoni urts }\end{array}$ & 13546 & $\begin{array}{l}\text { Fresh and dried } \\
\text { leaves, herbs }\end{array}$ & $\begin{array}{l}\text { CUL: Tea, as spice for soups, meat } \\
\text { dishes and cheese. MED: Infusion and } \\
\text { tea mistaken for thyme. }\end{array}$ \\
\hline $\begin{array}{l}\text { Ziziphora clinopodioides subsp. rigida } \\
\text { (Boiss.) Rech.f. [syn. Z. rigida (Boiss.) } \\
\text { Stapf] }\end{array}$ & $\begin{array}{l}\text { Urtsadaghdz, } \\
\text { limoni urts }\end{array}$ & 13544 & $\begin{array}{l}\text { Fresh and dried } \\
\text { leaves, herbs }\end{array}$ & $\begin{array}{l}\text { CUL: Tea, as spice for soups, meat } \\
\text { dishes and cheese. MED: Infusion and } \\
\text { tea mistaken for thyme. }\end{array}$ \\
\hline \multicolumn{5}{|l|}{ Lythraceae } \\
\hline Punica granatum L. & Nur & 13580 & $\begin{array}{l}\text { Fresh and dried } \\
\text { flowers and fruits, } \\
\text { dried bark of fruits }\end{array}$ & $\begin{array}{l}\text { CUL: Juice, jam, sweets. Tea from dried } \\
\text { flowers and fruits. MED: Infusion of dried } \\
\text { bark of fruits against respiratory system } \\
\text { diseases and diarrhoea. Dried fruits for } \\
\text { handicrafts as a traditional decorative } \\
\text { element. DEC. }\end{array}$ \\
\hline
\end{tabular}


Table 3 Wild plants sold in Yerevan's markets (Continued)

\begin{tabular}{|c|c|c|c|c|}
\hline Family/species & $\begin{array}{l}\text { Main local } \\
\text { name }\end{array}$ & $\begin{array}{l}\text { Voucher no. in ERCB } \\
\text { and conservation status }\end{array}$ & Used parts & Ways of use \\
\hline \multicolumn{5}{|l|}{ Malvaceae } \\
\hline Malva neglecta Wallr. & Phiphert & 13565 & Leaves & $\begin{array}{l}\text { CUL: Soups, fried. MED: Infusion against } \\
\text { stomach, intestine and kidney diseases, } \\
\text { hypertension. }\end{array}$ \\
\hline Malva pusilla Sm. & Phiphert & 13492 & Leaves & $\begin{array}{l}\text { CUL: Soups, fried. MED: Infusion against } \\
\text { stomach, intestine and kidney diseases, } \\
\text { hypertension. }\end{array}$ \\
\hline
\end{tabular}

Malva sylvestris L. $\quad$ Phiphert $13570 \quad$ Leaves

CUL: Soups, fried. MED: Infusion against stomach, intestine and kidney diseases, hypertension.

Moraceae

Ficus carica L.

Tzeni

13534

Morus alba $\mathrm{L}$.

Tteni spitak

13540

Morus nigra L.

Tteni sev

Orobanchaceae

Phelypaea tournefortii Desf.

Yot eghbor

13379 aryun, chibukh,

lala

Papaveraceae

Chelidonium majus L.

Tsitsernakhot

13472

Herbs, latex

Fresh and dried fruits, leaves, wood

Flowers

Fresh and dried fruits, leaves, wood

Fresh and dried fruits, latex

CUL: Jam, fresh and dried fruits. MED: Boiled with milk fruits against haemorrhoids. Latex as an anti-wart drug. Fresh and dried fruits for constipation. DEC.

CUL: Juice, jam, Syrup, sweets, vodka. WOOD: For vine barrels, musical instruments (saz). MED: Syrup against coughs. Infusion of leaves for diarrhoea, as hypoglycaemic agent. DEC.

CUL: Juice, jam, Syrup, sweets, vodka. WOOD: For vine barrels, musical instruments (saz). MED: Syrup against coughs. Infusion of leaves as hypoglycaemic agent. More useful than white mulberry. DEC.

DEC: Decoration only.

CUL: As a means of protecting plants from aphids. MED: Infusion for neoplasms and as an anti-inflammatory agent against diseases of the female reproductive system. Latex as an antiwart drug. REP.

Pinaceae

Pinus kochiana Klotzsch ex KKoch

13522

Green female cones, pollen, resin, wood

Fresh and dried leaves, seeds

Plantago major L.

Ezan lezu cones as sweets, also MED: Against coughs and diseases of the respiratory system. Powdered pollen against asthma. Resin as an antibacterial agent. WOOD: For handicrafts, doors, saunas.

CUL: Fried, filling for pies. MED: Infusion intestines diseases. Fresh leaves as a wound healing agent, for the treatment bites of insects. Mucilage of seeds for constipation.

CUL: Fried, filling for pies. MED: Mucilage of seeds for constipation.
CUL: Jam and syrup from green female or fresh leaves against stomach and 
Table 3 Wild plants sold in Yerevan's markets (Continued)

\begin{tabular}{|c|c|c|c|c|}
\hline Family/species & $\begin{array}{l}\text { Main local } \\
\text { name }\end{array}$ & $\begin{array}{l}\text { Voucher no. in ERCB } \\
\text { and conservation status }\end{array}$ & Used parts & Ways of use \\
\hline \multicolumn{5}{|l|}{ Polygonaceae } \\
\hline Rumex acetosa $\mathrm{L}$. & Trtnjuk & 13568 & Fresh leaves & $\begin{array}{l}\text { CUL: Soups, salads, fried, filling for pies. } \\
\text { MED: Infusion against liver diseases, } \\
\text { boiled herb for constipation. }\end{array}$ \\
\hline Rumex acetosella $\mathrm{L}$. & Trtnjuk & 13573 & Fresh leaves & $\begin{array}{l}\text { CUL: Soups, salads, fried, filling for pies. } \\
\text { MED: Infusion against liver diseases, } \\
\text { boiled herb for constipation. }\end{array}$ \\
\hline Rumex alpinus $\mathrm{L}$. & Aveluk & 13571 & Fresh and dried leaves & $\begin{array}{l}\text { CUL: Soups, salads, fried, filling for pies. } \\
\text { MED: Infusion against stomach and liver } \\
\text { diseases and from diarrhoea, boiled } \\
\text { herb for constipation. As embrocation } \\
\text { against skin diseases and compress } \\
\text { against a sore throat. }\end{array}$ \\
\hline Rumex crispus L. & Aveluk & 13240 & Fresh and dried leaves & $\begin{array}{l}\text { CUL: Soups, salads, fried, filling for pies. } \\
\text { MED: Infusion against digestive } \\
\text { disorders, stomach and liver diseases } \\
\text { and from diarrhoea, cough, boiled herb } \\
\text { for constipation. As embrocation against } \\
\text { skin and female reproductive system } \\
\text { diseases. As compress against a sore } \\
\text { throat. }\end{array}$ \\
\hline Rumex tuberosus L. & Aveluk & 13168 & Fresh and dried leaves & $\begin{array}{l}\text { CUL: Soups, salads, fried, filling for pies. } \\
\text { MED: Infusion against digestive } \\
\text { disorders, stomach, liver diseases and } \\
\text { from diarrhoea, cough, boiled herb for } \\
\text { constipation. As embrocation against } \\
\text { skin and diseases of the female } \\
\text { reproductive system. }\end{array}$ \\
\hline
\end{tabular}

Portulaceae

Portulaca oleracea L. Dandur

Primulaceae

Primula veris subsp. macrocalyx (Bunge) Lüdi

Gnarbuk, jangyulum

\section{Rhamnaceae}

Ziziphus jujuba Mill.

Unab

Crataegus ambigua C.A.Mey. ex

A.K.Becker [syn. Crataegus

atrosanguinea Pojark.]

Crataegus caucasica K.Koch

Crataegus meyeri Pojark.

Crataegus orientalis Pall. ex M.Bieb.

Szni, alotcheni 13578

Crataegus pentagyna Waldst. and Kit. Szni, alotcheni ex Willd.
Young leaves and stems

Flowers

Fresh and dried fruits

Fresh and dried fruits, dried flowers

Fresh and dried fruits, dried flowers

Fresh and dried fruits, dried flowers

Fresh and dried fruits, dried flowers

Fresh and dried fruits, dried flowers
CUL: Salads, boiled, lacto-fermented. MED: Infusion against liver, stomach, kidney, and bladder diseases, as hypoglycaemic agent.

DEC: Decorative plant is a part of a traditional spring game. MED: Infusion of flowers against respiratory system diseases and headache. DEC.

CUL: Fresh and dried fruits. MED: As a multivitamin and diuretic agent. DEC.

CUL: Juice, jam, liqueur, tea. MED: Tincture and infusion for heart diseases, fruits as multivitamin. DEC.

CUL: Juice, jam, liqueur, tea. MED: Tincture and infusion for heart diseases, fruits as multivitamin. DEC.

CUL: Juice, jam, liqueur, tea. MED: Tincture and infusion for heart diseases, fruits as multivitamin. DEC

CUL: Juice, jam, liqueur, tea. MED: Tincture and infusion for heart diseases, fruits as multivitamin. Most used. DEC.

CUL: Juice, jam, liqueur, tea. MED: Tincture and infusion for heart diseases, fruits as multivitamin. DEC. 
Table 3 Wild plants sold in Yerevan's markets (Continued)

\begin{tabular}{|c|c|c|c|c|}
\hline Family/species & $\begin{array}{l}\text { Main local } \\
\text { name }\end{array}$ & $\begin{array}{l}\text { Voucher no. in ERCB } \\
\text { and conservation status }\end{array}$ & Used parts & Ways of use \\
\hline Crataegus rhipidophylla Gand. & Szni, alotcheni & 13581 & $\begin{array}{l}\text { Fresh and dried fruits, } \\
\text { dried flowers }\end{array}$ & $\begin{array}{l}\text { CUL: Juice, jam, liqueur, tea. MED: } \\
\text { Tincture and infusion for heart diseases, } \\
\text { fruits as multivitamin. DEC. }\end{array}$ \\
\hline Fragaria vesca $\mathrm{L}$. & Getnamori & 13537 & $\begin{array}{l}\text { Fresh and dried fruits, } \\
\text { herbs }\end{array}$ & $\begin{array}{l}\text { CUL: Juice, jam, tea. MED: Infusion or } \\
\text { tea of herb against kidney and bladder } \\
\text { diseases, as a diuretic agent, fruits as a } \\
\text { multivitamin. DEC. }\end{array}$ \\
\hline Malus orientalis Uglitzk. & Khndzoreni & & Fresh and dried fruits & $\begin{array}{l}\text { CUL: Juice, jam, lacto-fermented, sweets } \\
\text { and candy, vinegar, liqueur. MED: Fruits } \\
\text { as a multivitamin and as a source of } \\
\text { iron against blood diseases. DEC. }\end{array}$ \\
\hline Mespilus germanica L. & Zkereni & 13505 & Fresh fruits & $\begin{array}{l}\text { CUL: Lacto-fermented and fresh fruits. } \\
\text { MED: Puree of ripe fruits against } \\
\text { digestive disorders, constipation and for } \\
\text { rebuilding strength after prolonged } \\
\text { illness, fruits as a multivitamin. DEC. }\end{array}$ \\
\hline Prunus armeniaca $\mathrm{L}$. & Tsiraneni & 13541 & $\begin{array}{l}\text { Fresh, frozen and } \\
\text { dried fruits, flowers, } \\
\text { seeds, wood }\end{array}$ & $\begin{array}{l}\text { CUL: Fruits used to make soup, juice, } \\
\text { jam, liqueur, paste, and sweets. Dried } \\
\text { flowers and fruits for tea. WOOD: For } \\
\text { musical instruments (duduk, tar, } \\
\text { qyamancha, zurna) and handicrafts. } \\
\text { MED: Fruits as a multivitamin, as a } \\
\text { source of potassium against heartache } \\
\text { and for constipation. DEC. }\end{array}$ \\
\hline Prunus divaricata Ledeb. & $\begin{array}{l}\text { Saloreni, } \\
\text { shloreni }\end{array}$ & & $\begin{array}{l}\text { Fresh, frozen and } \\
\text { dried fruits, flowers, } \\
\text { wood }\end{array}$ & $\begin{array}{l}\text { CUL: Used to make juice, jam, liqueur, } \\
\text { lacto-fermented, spice, paste, sweets } \\
\text { and candy. WOOD: for musical } \\
\text { instruments (saz). MED: Dried fruits } \\
\text { against constipation, fruits as a } \\
\text { multivitamin. DEC. }\end{array}$ \\
\hline Prunus microcarpa C.A.Mey. & Baleni & & Fresh and dried fruits & $\begin{array}{l}\text { CUL: Juice, liqueur, sweets. Fruits as a } \\
\text { multivitamin. }\end{array}$ \\
\hline Prunus spinosa $\mathrm{L}$. & Mamkheni & & $\begin{array}{l}\text { Fresh, frozen and } \\
\text { dried fruits }\end{array}$ & $\begin{array}{l}\text { CUL: Juice, jam, liqueur, lacto-fermented, } \\
\text { spice, paste, sweets and candy. MED: } \\
\text { Dried fruits against constipation, as a } \\
\text { multivitamin, as a diuretic and } \\
\text { expectorant agent. DEC. }\end{array}$ \\
\hline Pyrus salicifolia Pall. & Tandzeni & 13536 & Fresh and dried fruits & $\begin{array}{l}\text { CUL: Juice, jam, liqueur, lacto-fermented, } \\
\text { paste, sweets and candy. MED: Fresh } \\
\text { and dried fruits used for diarrhoea. DEC. }\end{array}$ \\
\hline Pyrus caucasica Fed. & Tandzeni & 13520 & Fresh and dried fruits & $\begin{array}{l}\text { CUL: Juice, jam, liqueur, lacto-fermented, } \\
\text { paste, sweets and candy. MED: Fresh } \\
\text { and dried fruits from diarrhoea. DEC. }\end{array}$ \\
\hline Rosa canina $\mathrm{L}$. & Masreni & 13538 & $\begin{array}{l}\text { Fresh and dried fruits, } \\
\text { petals, oil }\end{array}$ & $\begin{array}{l}\text { CUL: Fresh, dried fruits and petals for } \\
\text { juice, jam, liqueur, tea, petals as a spice } \\
\text { for sweets and candy. MED: Oil in } \\
\text { cosmetology. Infusion of fruits used } \\
\text { against colds, stomach and intestine } \\
\text { diseases, for strength after prolonged } \\
\text { illness, and as a multivitamin and as a } \\
\text { diuretic agent. DEC. }\end{array}$ \\
\hline Rosa corymbifera Borkh. & Masreni & 13547 & $\begin{array}{l}\text { Fresh and dried fruits, } \\
\text { petals, oil }\end{array}$ & $\begin{array}{l}\text { CUL: Fresh, dried fruits and petals for } \\
\text { juice, jam, liqueur, tea, petals as a spice } \\
\text { for sweets and candy. MED: Oil used in } \\
\text { cosmetology. Infusion of fruits against } \\
\text { colds, stomach and intestine diseases, } \\
\text { for strength after prolonged illness, as a } \\
\text { multivitamin and as a diuretic agent. } \\
\text { DEC. }\end{array}$ \\
\hline
\end{tabular}


Table 3 Wild plants sold in Yerevan's markets (Continued)

\begin{tabular}{|c|c|c|c|c|}
\hline Family/species & $\begin{array}{l}\text { Main local } \\
\text { name }\end{array}$ & $\begin{array}{l}\text { Voucher no. in ERCB } \\
\text { and conservation status }\end{array}$ & Used parts & Ways of use \\
\hline Rosa spinosissima L. & Masreni & 13584 & $\begin{array}{l}\text { Fresh and dried fruits, } \\
\text { petals, oil }\end{array}$ & $\begin{array}{l}\text { CUL: Fresh, dried fruits and petals for } \\
\text { juice, jam, liqueur, tea, petals as a spice } \\
\text { for sweets and candy. MED: Oil in } \\
\text { cosmetology. Infusion of fruits against } \\
\text { colds, stomach and intestine diseases, } \\
\text { for strength after prolonged illness, as a } \\
\text { multivitamin and as a diuretic agent. } \\
\text { DEC. }\end{array}$ \\
\hline Rubus anatolicus Focke & Mosheni & & $\begin{array}{l}\text { Fresh, frozen and } \\
\text { dried fruits, leaves }\end{array}$ & $\begin{array}{l}\text { CUL: Fruits for juice, jam, compote, } \\
\text { liqueur, sweets, fruits and leaves used as } \\
\text { a tea. MED: As a multivitamin, a diuretic } \\
\text { agent against colds. }\end{array}$ \\
\hline Rubus caesius L. & Mosheni & 13583 & $\begin{array}{l}\text { Fresh, frozen and } \\
\text { dried fruits, leaves }\end{array}$ & $\begin{array}{l}\text { CUL: Fruits for juice, jam, compote, } \\
\text { liqueur, sweets, fruits and leaves used as } \\
\text { a tea. MED: As a multivitamin, a diuretic } \\
\text { agent against colds. }\end{array}$ \\
\hline Rubus idaeus L. & Moreni & 13585 & $\begin{array}{l}\text { Fresh, frozen and } \\
\text { dried fruits, leaves }\end{array}$ & $\begin{array}{l}\text { CUL: Fruits for juice, jam, compote, } \\
\text { liqueur, sweets, fruits and leaves used as } \\
\text { a tea. MED: As a multivitamin, a diuretic } \\
\text { agent against colds. }\end{array}$ \\
\hline Sorbus aucuparia L. & Aroseni & 13486 & $\begin{array}{l}\text { Fresh, frozen and } \\
\text { dried fruits }\end{array}$ & $\begin{array}{l}\text { CUL: Fruits for compote, liqueur, tea. } \\
\text { MED: As a multivitamin, a diuretic and a } \\
\text { choleretic agent, infusion for heart } \\
\text { muscle treatment. DEC. }\end{array}$ \\
\hline
\end{tabular}

\section{Rubiaceae}

Rubia tinctorum L.
Toron

13518

Ureni

Salix spp.

Tiliaceae

Tilia cordata Mill.

Urticaceae

Urtica dioica $\mathrm{L}$.

Eghinj

13521
Roots, fruits

Branches

Inflorescence, wood

Young leaves
Young leaves, fresh and dried fruits
DEC: Dye for Easter eggs and threads. MED: Infusion of roots used as a diuretic agent against kidney and bladder diseases.

WOOD: Withes for baskets, wreaths. Spring garlands on Palm Sunday. DEC.

CUL: Tea. WOOD: Handicrafts. MED: Infusion or tea from inflorescence against colds, cough and respiratory system diseases. DEC.

CUL: Soups, fried, salads, as a filling for pies. MED: Infusion as a multivitamin, a diuretic agent, for the prevention of bleeding of the uterus, herbs boiled against constipation and haemorrhoids.

CUL: Young leaves for dolma (stuffed leaves with meat), fruits in the form of compote, jam, sweets, candy, wine, syrup, vinegar, raisins. DEC.

CUL culinary, MED medical, DEC decorative, REP insect repellent

\section{Authors' contributions}

All the authors took part in elaborating the concept of the study, in writing the article, and read and approved the final version of the paper. SN, NZ and NK gathered the field data and collected the specimens.

\section{Funding}

The research was partially financed by the National Geographic grant GEFNE 192-16 (2017).
Availability of data and materials

For voucher specimens, see the "Methods" section.

\section{Ethics approval and consent to participate}

The research adhered to the local traditions for such research, the Code of Ethics of the International Society of Ethnobiology [87]. Prior oral informed consent was obtained from all study participants. No ethical committee permits were required. No permits were required to collect voucher specimens. 


\section{Consent for publication}

Not applicable.

\section{Competing interests}

The authors declare that they have no competing interests.

\section{Author details}

'Department of Botany and Mycology, Yerevan State University, A. Manoogian, 1, 0025 Yerevan, Armenia. ²Department of Microbiology and Parasitology, Institute of Biology, Jan Kochanowski University, Uniwersytecka 7, 25-406 Kielce, Poland. ${ }^{3}$ Institute of Biology and Biotechnology, University of Rzeszów, Pigonia 1, 35-310 Rzeszów, Poland.

\section{Received: 6 February 2020 Accepted: 22 April 2020 Published online: 19 May 2020}

\section{References}

1. Mittermeier RA, Gil RP, Hoffman M, Pilgrim J, Brooks T, Mittermeier CG, Lamoreux J, Fonseca GAB. Hotspots revisited: earth's biologically richest and most endangered terrestrial ecoregions. Boston: University of Chicago Press; 2005.

2. Comrie B. Linguistic diversity in the Caucasus. Annu Rev Anthropol. 2008;37: 131-43.

3. Barbujani G, Nasidze IS, Whitehead GN. Genetic diversity in the Caucasus. Hum Biol. 1994;1:639-68.

4. Grossgeim AA. Rastitel'nye resursy Kavkaza (plant resources of the Caucasus). Academy of Sciences of Azerbaijan: Baku; 1946.

5. Vavilov NI, Vavylov MI, Vavílov NÍ, Dorofeev VF. Origin and geography of cultivated plants. Cambridge: Cambridge University Press; 1992.

6. Bussmann RW, editor. Ethnobotany of the Caucasus. New York: Springer International Publishing; 2017.

7. Bussmann RW, Paniagua Zambrana NY, Sikharulidze S, Kikvidze Z, Kikodze D, Tchelidze D, Batsatsashvili K, Hart RE. Medicinal and food plants of Svaneti and Lechkhumi, Sakartvelo (Republic of Georgia), Caucasus. Med Aromat Plants. 2016b;5(266):2167-0412.

8. Bussmann RW, Zambrana NY, Sikharulidze S, Kikvidze Z, Kikodze D, Jinjikhadze T, Shanshiashvili T, Chelidze D, Batsatsashvili K, Bakanidze N. Wine, beer, snuff, medicine, and loss of diversity-ethnobotanical travels in the Georgian Caucasus. Ethnobot Res Appl. 2014;12:237-313.

9. Bussmann RW, Paniagua-Zambrana NY, Sikharulidze S, Kikvidze Z, Kikodze D, Tchelidze D, Batsatsashvili K, Hart RE. Plant and fungal use in Tusheti, Khevsureti, and Pshavi, Sakartvelo (Republic of Georgia), Caucasus. Acta Soc Bot Pol. 2017;86(2).

10. $Ł$ uczaj $Ł$, Tvalodze B, Zalkaliani D. Comfrey and buttercup eaters: wild vegetables of the Imereti Region in Western Georgia, Caucasus. Econ Bot. 2017;71(2):188-93.

11. Pieroni A, Sõukand R. Ethnic and religious affiliations affect traditional wild plant foraging in Central Azerbaijan. Genet Resour Crop Evol. 2019;66(7): 1495-513.

12. Sõukand R, Pieroni A. Resilience in the mountains: biocultural refugia of wild food in the Greater Caucasus Range, Azerbaijan. Biodivers Conserv. 2019; 28(13):3529-45.

13. Fayvush GM, Aleksanyan AS, Bussmann RW. Ethnobotany of the CaucasusArmenia. In Bussmann R, editor. Ethnobotany of the Caucasus. Springer International Publishing; 2017. p. 21-36.

14. Kaliszewska I, Kołodziejska-Degórska I. The social context of wild leafy vegetables uses in Shiri, Daghestan. J Ethnobiol Ethnomed. 2015;11:63.

15. Hovsepyan R, Stepanyan-Gandilyan N, Melkumyan H, Harutyunyan L. Food as a marker for economy and part of identity: traditional vegetal food of Yezidis and Kurds in Armenia. J Ethn Food. 2016;3(1):32-41.

16. Fifth national report to the convention on biological diversity, Yerevan, 2014. https://www.cbd.int/doc/world/am/am-nr-05-en.pdf. Accessed 23 Nov 2019.

17. Pieroni A, Hovsepyan R, Manduzai AK, Sõukand R. Wild food plants traditionally gathered in central Armenia: archaic ingredients or future sustainable foods?. Environment, Development and Sustainability. 2020. https://doi.org/https://doi.org/10.1007/s10668-020-00678-1.

18. Bussmann RW, Paniagua Z, Narel Y, Sikharulidze S, Kikvidze Z, Kikodze D, Tchelidze D, Batsatsashvili K, Robbie E. Plants in the spa-the medicinal plant market of Borjomi, Sakartvelo (Republic of Georgia), Caucasus. Indian J Tradit Know. 2017;16:25-34.
19. Bye RA. Medicinal plants of the Sierra Madre: comparative study of Tarahumara and Mexican Market Plants. Econ Bot. 1986;40(1):103-24.

20. Nguyen ML, Doherty KT, Wieting J. Market survey research: a model for ethnobotanical education. Ethnobot Res Appl. 2008;17(6):087-92.

21. Muszyński. Wileńskie zioła ludowe. Wiadomości Farmaceutyczne. 1927;2122:469-476.

22. Szulczewski JW. Grzyby sprzedawane na targach Poznania. Rocznik Nauk Rolniczych i Leśnych. 1933;29:1-12.

23. Szulczewski JW. O handlu roślinami leczniczemi na targach w Poznaniu. Poznań: Wydawnictwo Okręgowego Komitetu Ochrony Przyrody w Poznaniu; 1935. p. 80-7.

24. Penzes A. Budapesti viragok. Kerteszeti Lapok. 1926a;8:113-4.

25. Penzes A. Budapesti viragok. - Kerteszeti Lapok 1926b;9:130-131.

26. Karousou R, Deirmentzoglou S. The herbal market of Cyprus: traditional links and cultural exchanges. J Ethnopharmacol. 2011:133:191-203.

27. Hanlidou E, Karousou R, Kleftoyanni V, Kokkini S. The herbal market of Thessaloniki ( $N$ Greece) and its relation to the ethnobotanical tradition. Ethnopharmacol. 2004;91:281-99.

28. Łuczaj Ł, Zovko-Končić M, Miličević T, Dolina K, Pandža M. Wild vegetable mixes sold in the markets of Dalmatia (southern Croatia). J Ethnobiol Ethnomed. 2013;9:2.

29. Ertug F. Wild edible plants of the Bodrum Area (Mugla, Turkey). Turk J Bot. 2004;28:161-74.

30. Dogan Y, Ugulu I, Durkan N. Wild edible plants sold in the local markets of Izmir, Turkey. Pak J Bot. 2013:45(S1):177-84.

31. Nedelcheva A, Dogan Y. An ethnobotanical study on wild medicinal plants sold in the local markets at both sides of the Bulgarian-Turkish border. Planta Medica. 2015;81(16)

32. Dogan $Y$, Nedelcheva A. Wild plants from open markets on both sides of the Bulgarian-Turkish border. Ind J Trad Know. 2015;14(3):351-8.

33. Pemberton RW, Lee NS. Wild food plants in South Korea; market presence, new crops, and exports to the United States. Econ Bot. 1996;50(1):57-70.

34. Xu YK, Tao GD, Liu HM, Yan KL, Dao XS. Wild vegetable resources and market survey in Xishuangbanna southwest China. Econ Bot. 2004;58(4): 647-67

35. Shirai Y, Rambo AT. Urban demand for wild foods in Northeast Thailand: a survey of edible wild species sold in the Khon Kaen municipal market. Ethnobot Res Appl. 2014;12:113-29.

36. Konsam S, Thongam B, Handique AK. Assessment of wild leafy vegetables traditionally consumed by the ethnic communities of Manipur, northeast India. J Ethnobiol Ethnomed. 2016;12:1.

37. Mati $\mathrm{E}$, de Boer $\mathrm{H}$. Ethnobotany and trade of medicinal plants in the Qaysari Market, Kurdish Autonomous Region, Iraq. J Ethnopharmacol. 2011;133(2): 490-510.

38. Vlkova M, Verner V, Kandakov A, Polesny Z, Karabaev N, Pawera L Nadvornikowa I, Banout J. Edible plants sold on marginal rural markets in Fergana Valley, southern Kyrgyzstan. Bulg J Agricult Sci. 2015;21(2):243-50.

39. Hamayun M, Khan MA, Begum S. Marketing of medicinal plants of UtrorGabral Valleys, Swat, Pakistan. Ethnobot Leaflets. 2003;2003(1):13.

40. Amiri MS, Joharchi MR. Ethnobotanical investigation of traditional medicinal plants commercialized in the markets of Mashhad, Iran. Avicenna J Phytomed. 2013;3:254-71.

41. Dénes A. Wild plants for sale in the markets of Pécs then and now (Baranya Hungary). Acta Ethnographica Acad Sci Hung. 2017;62(2):339-71.

42. Li DL, Zheng XL, Duan L, Deng SW, Ye W, Wang AH, Xing FW. Ethnobotanical survey of herbal tea plants from the traditional markets in Chaoshan, China. J Ethnopharmacol. 2017;205:195-206.

43. Silalahi M, Walujo EB, Supriatna J, Mangunwardoyo W. The local knowledge of medicinal plants trade and diversity of medicinal plants in the Kabanjahe traditional market, North Sumatra, Indonesia. J Ethnopharmacol. 2015;175: 432-43.

44. Sucholas J. Zioła i rośliny świąteczne miejskiego targowiska w Poznaniu (Wielkopolska): powrót do badań Szulczewskiego po 80 latach. Herbs and ceremonial plants of the urban marketplace in Poznan (Greater Poland): Szulczewski's study revisited after 80 years. Etnobiologia Polska. 2016;6:7-30.

45. Dibong SD, Ottou PB, Vandi D, Ndjib RC, Tchamaha FM, Mpondo EM. Ethnobotany of anti-hemorrhoidal plants in markets and villages in the central and littoral regions of Cameroon. J Appl Biosci. 2015;96:9072-93.

46. Nguyen TS, Xia NH, Van Chu T, Van Sam H. Ethnobotanical study on medicinal plants in traditional markets of Son La province, Vietnam. Forest Soc. 2019;3(2):171-92. 
47. Kar A, Borthakur SK. Wild vegetables sold in local markets of Karbi Anglong, Assam. Indian J Tradit Knowl. 2007;6(1):169-72.

48. Salam S, Jamir NS, Singh PK. Wild leafy vegetables sold in local markets of Ukhrul District of Manipur, India. Pleione. 2012;6(2):298-303.

49. Zhang L, Zhuang H, Zhang Y, Wang L, Zhang Y, Geng Y, Gou Y, Pei S, Wang Y. Plants for health: an ethnobotanical 25-year repeat survey of traditional medicine sold in a major marketplace in North-west Yunnan, China. J Ethnopharmacol. 2018;224:119-25.

50. Martin G. Searching for plants in peasant market-places. In: Plotkin MJ, Famolare $L$, editors. Sustainable harvest and marketing of rainforest products. Washington, DC: Island Press, Washington; 1992. p. 212-23.

51. Cruz-Garcia G, Lagunez-Rivera L, Chavez-Angeles MG, Solano-Gomez R. The wild orchid trade in a Mexican local market: diversity and economics. Econ Bot. 2015;69(4):291-305.

52. Boa E. Wild edible fungi: a global overview of their use and importance to people. In: Non-wood forest products 17. Rome: FAO; 2004.

53. Kasper-Pakosz R, Pietras M, Łuczaj $Ł$. Wild and native plants and mushrooms sold in the open-air markets of south-eastern Poland. J Ethnobiol Ethnomed. 2016;12(1):45

54. Liu D, Cheng H, Bussmann RW, Guo Z, Liu B, Long C. An ethnobotanical survey of edible fungi in Chuxiong City, Yunnan, China. J Ethnobiol Ethnomed. 2018;14(1):42

55. Sulaini AA, Sabran SF. Edible and medicinal plants sold at selected local markets in Batu Pahat, Johor, Malaysia. InAIP Conference Proceedings 2018 Aug 15 (Vol. 2002, No. 1, p. 020006). AlP Publishing. https://doi.org/https:// doi.org/10.1063/1.5050102

56. Franco FM, Chaw LL, Bakar N, Abas SN. Socialising over fruits and vegetables: the biocultural importance of an open-air market in Bandar Seri Begawan, Brunei Darussalam. J Ethnobiol Ethnomed. 2020;16:6.

57. Vardanyan SA. The history of Armenian medicine from antiquity to the present day, Regimedia; 2007.

58. Nanagulyan SG. Applied research on edible mushrooms in the Republic of Armenia. In: Balkema AA, editor. Proceedings "Science and cultivation of edible fungi". Rotterdam: Brookfield; 2000. p. 783-7.

59. Fayvush GM, Aleksanyan AS. Mestoobitanija Armenii [Habitats of Armenia]. Institute of Botany NAS RA: Yerevan; 2016.

60. Magakyan AK. Rastitel'nost' Armjanskoj SSR [Vegetation of Armenian SSR]. Moscow-Leningrad; 1941

61. Fayvush GM. Flora diversity of Armenia. In: Biodiversity of Armenia. From materials of the Third National Report. Yerevan; 2008, p. 9-12.

62. Piwowarczyk R, Sánchez Pedraja O, Moreno Moral G, Fayvush G, Zakaryan N, Kartashyan N, Aleksanyan A. Holoparasitic Orobanchaceae (Cistanche, Diphelypaea, Orobanche, Phelipanche) in Armenia: distribution, habitats, host range and taxonomic problems. Phytotaxa. 2019;386(1):1-106.

63. Takhtajan AL. Botanico-geographicheskij ocherk Armenii [Phytogeographical review of Armenia]. Proc. Institute of Botany of Armenian branch of USSR Academy of Sciences. 1941;2:3-156.

64. HH mshtakan bnakchutyan tvaqanak. The official estimate of the population in Armenia. Yerevan, 2016 [in Armenian]. https://www.armstat.am/file/ article/nasel_01.01.2016.pdf. Accesed 10 Sept 2019.

65. Tamanyan KG, Fayvush GM, Nanagyulyan SG, Danielyan TS, editors. The red book of plants of Republic of Armenia (higher plants and fungi). Yerevan: Zangak Publishing House; 2010.

66. Takhtajan AL, Fedorov AA. Flora Erevana: Opredelitel' Dikorastushchikh Rastenii Araratskoi kotloviny. In: Flora of Yeravan: keys to the wild plants of the Ararat basin. Leningrad: Nauka Press; 1972.

67. Takhtajan AL. (Ed). Flora Armenii [Flora of Armenia]., vol. 1-11; Yerevan: Izd. Akad. Nauk ArSSSR; 1954-2010.

68. Nanagulyan SG. Cap Fungi of Armenia (Agaricoid Basiodiomycetes) [in Russian]. Yerevan: YSU Press; 2008.

69. Melik-Khachatryan JH. Mycoflora of Armenian SSR [in Russian]. Agaricoid Fungi. V. 5. Yerevan: YSU Press; 1980.

70. The plant list. 2019. http://theplantlist.org/Accessed 23 Nov 2019.

71. Index Fungorum. 2019. http://www.indexfungorum.org/. Accessed 23 Nov 2019.

72. Łuczaj Ł. Archival data on wild food plants used in Poland in 1948. J Ethnobiol Ethnomed. 2008;4:4.

73. Wasson VP, Wasson RG. Mushrooms, Russia, and History. New York Pantheon Books; 1957.

74. Shkhagapsoiev SH, Shorova RC, Kozhkov MH. Dikorastushchie rastenija v tradicionnoj pishche kabardincev. Nalchik: Izdatel'skij Centr El'-fa; 2003.
75. Sõukand R, Pieroni A, Biró M, Dénes A, Dogan Y, Hajdari A, Kalle R, Reade B, Mustafa B, Nedelcheva A, Quave CL, Łuczaj $Ł$. An ethnobotanical perspective on traditional fermented plant foods and beverages in Eastern Europe. J Ethnopharmacol. 2015;170:284-96.

76. Katz SE. The art of fermentation: an in-depth exploration of essential concepts and processes from around the world. New York: Chelsea green publishing; 2012.

77. Borstel KV, Witte L, Hartmann T. Pyrrolizidine alkaloid patterns in populations of Senecio vulgaris, S. vernalis and their hybrids. Phytochemistry. 1989;28(6):1635-8.

78. Etkin NL. Medicinal cuisines: diet and ethopharmacology. Int J. Pharmacogn. 1996;34(5):313-26.

79. Pieroni A, Price $L$, editors. Eating and healing: traditional food as medicine. Boca Raton: CRC Press; 2006.

80. Varga F, Šolić I, Dujaković MJ, Łuczaj Ł, Grdiša M. The first contribution to the ethnobotany of inland Dalmatia: medicinal and wild food plants of the Knin area, Croatia. Acta Soc Bot Pol. 2019;88(2):3622. https://doi.org/https:// doi.org/10.5586/asbp.3622.

81. Sõukand R, Kalle R. Where does the border lie: locally grown plants used for making tea for recreation and/or healing, 1970s-1990s Estonia. J Ethnopharmacol. 2013;150(1):162-74.

82. Bhatia H, Sharma YP, Manhas RK, Kumar K. Traditionally used wild edible plants of district Udhampur, J\&K, India. J Ethnobiol Ethnomed. 2018;14:73.

83. Yeşil $Y$, Inal I. Traditional knowledge of wild edible plants in Hasankeyf (Batman Province, Turkey). Acta Soc Bot Pol. 2019;88(3):3633 https://doi.org/ 10.5586/asbp.3633.

84. Slow food. Ark of taste. 2019. https://www.fondazioneslowfood.com/en/ what-we-do/the-ark-of-taste /. Accessed 17 Jan 2019.

85. Kang Y, Luczaj L, Ye S, Zhang S, Kang J. Wild food plants and wild edible fungi of Heihe valley (Qinling Mountains, Shaanxi, central China): herbophilia and indifference to fruits and mushrooms. Acta Soc Bot Pol. 2012;81(4):405-13.

86. Łuczaj Ł, Köhler P, Pirożnikow E, Graniszewska M, Pieroni A, Gervasi T. Wild edible plants of Belarus: from Rostafiński's questionnaire of 1883 to the present. J Ethnobiol Ethnomed. 2013;9(1):21.

87. International society of ethnobiology code of ethics (with 2008 additions). http://ethnobiology.net/code-of-ethics/. Accessed 10 Dec 2019.

\section{Publisher's Note}

Springer Nature remains neutral with regard to jurisdictional claims in published maps and institutional affiliations.

\section{Ready to submit your research? Choose BMC and benefit from:}

- fast, convenient online submission

- thorough peer review by experienced researchers in your field

- rapid publication on acceptance

- support for research data, including large and complex data types

- gold Open Access which fosters wider collaboration and increased citations

- maximum visibility for your research: over $100 \mathrm{M}$ website views per year

At BMC, research is always in progress.

Learn more biomedcentral.com/submissions 